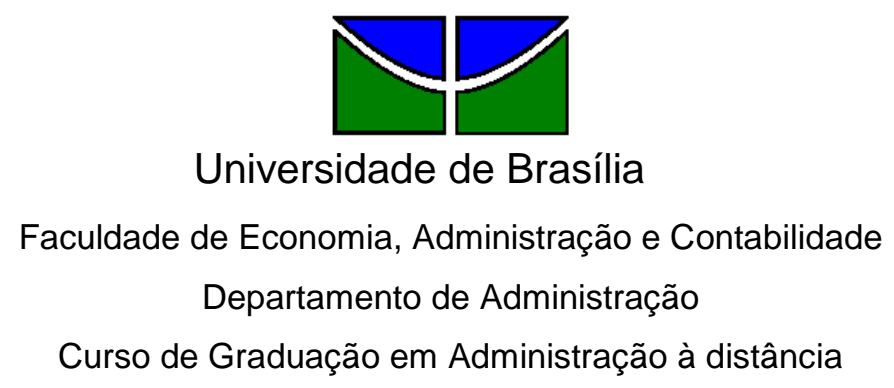

ANDRÉ FERREIRA DA COSTA

\title{
RESPONSABILIDADE SOCIAL: A efetividade do Programa de qualidade de vida - QVT na percepção do público interno em uma unidade bancária nacional.
}

Brasília - DF 


\section{ANDRÉ FERREIRA DA COSTA}

RESPONSABILIDADE SOCIAL: A efetividade do Programa de qualidade de vida - QVT na percepção do público interno em uma unidade bancária nacional.

Monografia apresentada a Universidade de Brasília (UnB) como requisito parcial para obtenção do grau de Bacharel em Administração.

Professor Orientador: Prof. MSC. Mariana Marlière Létti

Brasília - DF

2010 
Costa, André Ferreira da.

RESPONSABILIDADE SOCIAL: A efetividade do Programa de qualidade de vida - QVT na percepção do público interno em uma unidade bancária nacional./ André Ferreira da Costa - Brasília, 2010. $46 \mathrm{fl}$.

Monografia (bacharelado) - Universidade de Brasília, Departamento de Administração - EAD, 2010.

Orientador: Marianana Marlière Létti, MESTRE, Departamento de Administração.

1. Responsabilidade Social. 2. Colaboradores internos 3.Qualidade de Vida no Trabalho 


\title{
ANDRÉ FERREIRA DA COSTA
}

\section{RESPONSABILIDADE SOCIAL: A efetividade do Programa de qualidade de vida - QVT na percepção do público interno em uma unidade bancária nacional.}

A Comissão Examinadora, abaixo identificada, aprova o Trabalho de Conclusão do Curso de Administração da Universidade de Brasília do aluno:

\section{André Ferreira da Costa}

\author{
Prof. MSC. Mariana Marlière Létti \\ Professor-Orientador
}




\title{
RESUMO
}

Responsabilidade Social é um tema de extrema relevância que está presente no dia a dia das organizações modernas. O presente trabalho buscou evidenciar a percepção dos colaboradores internos, de uma instituição bancária nacional, em relação à efetividade do Programa de Qualidade de Vida no trabalho - QVT, adotado pela empresa como prática de responsabilidade social interna que busca promover a melhoria da qualidade de vida no trabalho. Para tanto escolhemos o estudo de caso único com abordagem quantitativa descritiva com a aplicação de um questionário composto de 10 questões fechadas. Concluímos que os colaboradores internos têm um grau satisfatório de conhecimento a cerca do conceito responsabilidade social e existe forte grau de incerteza quanto à efetividade do programa QVT adotado pela empresa, na percepção dos participantes da pesquisa.

Palavras chaves: Responsabilidade Social; Colaboradores internos; Qualidade de Vida no Trabalho.

\begin{abstract}
Social responsibility is a very important topic present in the everyday life of modern organizations. This study was intended to highlight the perception from a major national bank staff, regarding the effectiveness of the Program for Quality of Life at work-QVT. This program was recently adopted by the company as a practice of internal social responsibility aimed to promote and improve quality of life at work. We chose a single case study using a descriptive quantitative approach through a questionnaire consisting of closed questions. Based on the survey answers, the study concluded that employees have a good degree of knowledge about the concept of social responsibility and a high degree of uncertainty regarding the effectiveness of the QVT program adopted by the company.
\end{abstract}

Keywords: Social Responsibility; Internal employees; Quality of work life 


\section{Sumário}

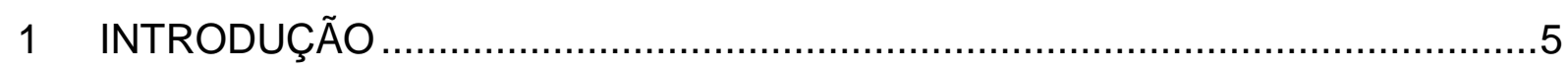

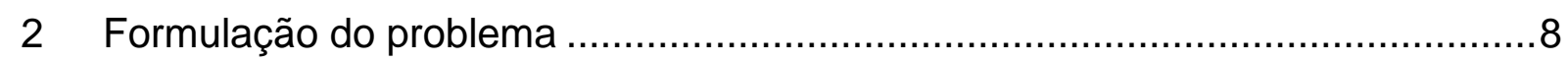

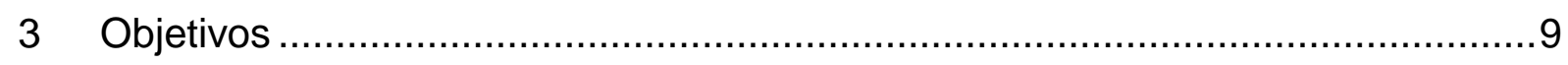

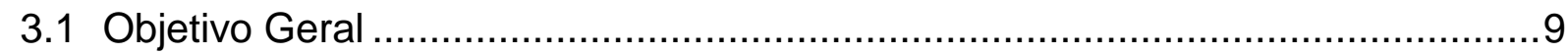

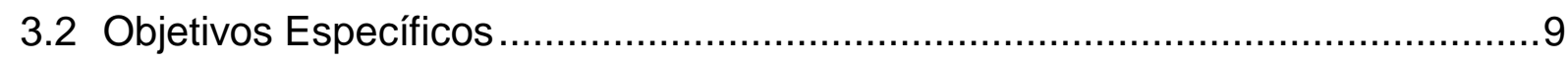

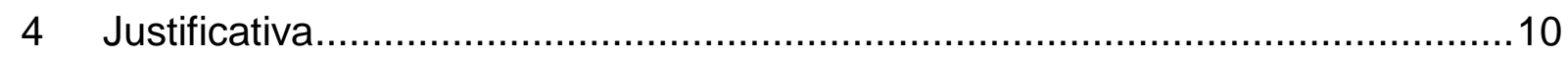

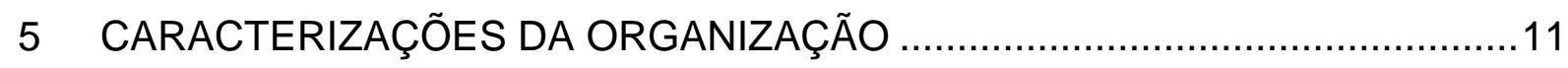

5.1 Princípios Éticos e Socioambientais do Banco Nacional S/A .............................12

5.2 Carta de Princípios de RS do banco Nacional S/A : .....................................13

5.3 Código de Ética do Banco Nacional S/A ........................................................ 14

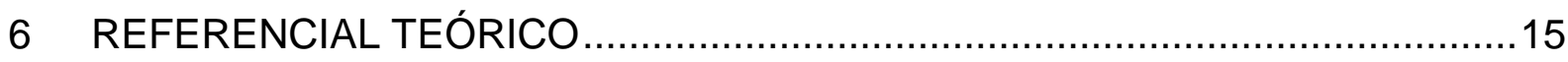

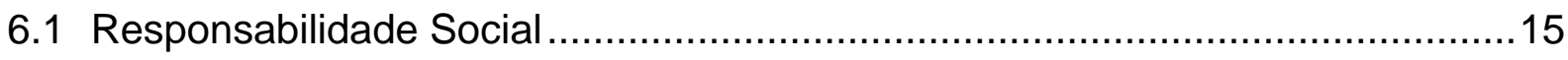

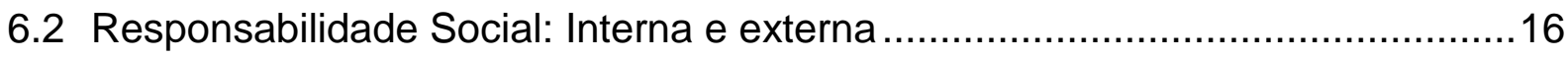

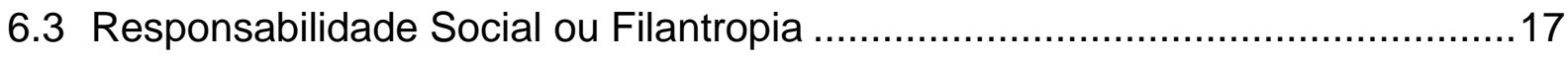

6.4 Responsabilidade Social Empresarial ...................................................... 18

7 MÉTODOS E TÉCNICAS DE PESQUISA ………........................................19

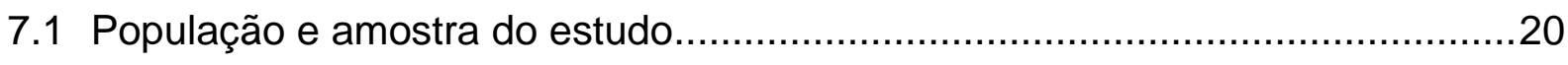

7.2 Caracterização dos instrumentos de pesquisa................................................21

7.3 Procedimentos de coleta e de análise de dados ...........................................21

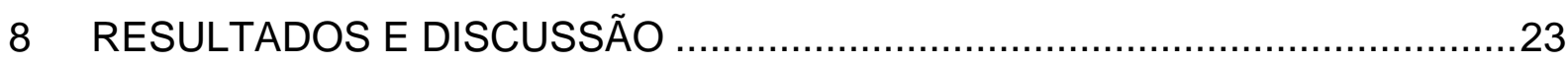

8.1 Caracterizações do Programa QVT do Banco Nacional S.A.............................23

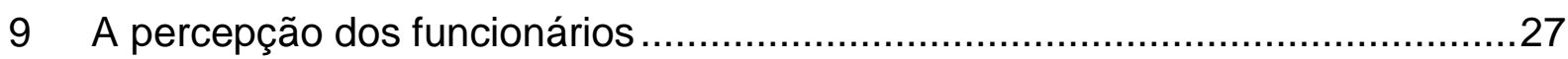

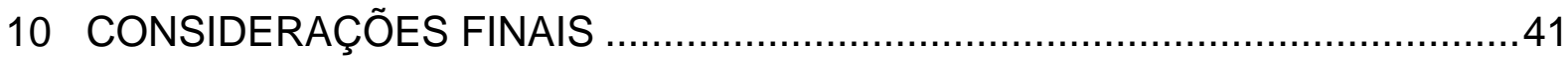

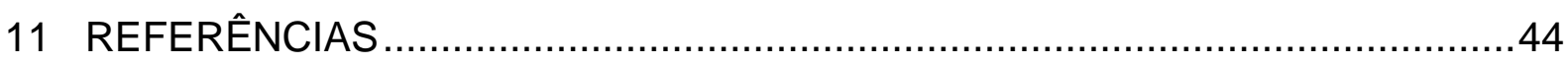

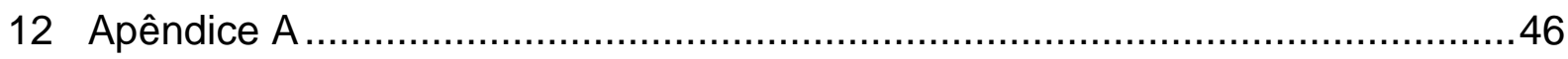




\section{INTRODUÇÃO}

Nas últimas décadas a preservação do planeta tornou-se imperativa, ante ao agravamento de problemas ambientais e sociais. Exaustão de recursos naturais. Os índices de pobreza e a degradação do meio ambiente chamam a atenção de governos e setores organizados da sociedade que unem forças em busca de alternativas e medidas que permitam o crescimento econômico de forma responsável e sustentável.

A sociedade é globalizada e cercada de avanços tecnológicos que proporcionam relevantes ganhos de desempenho de máquinas e equipamentos capazes de simplificar extremamente o processo produtivo. Porém os meios de produção continuam muito dependentes dos recursos naturais escassos. Por conta disto acordos e tratados foram criados entre governos e setores organizados da sociedade mundial em busca do desenvolvimento sustentável, ou seja, atender às necessidades presentes sem prejudicar o atendimento das necessidades futuras, conciliando as questões ambientais, sociais e econômicas.

Nesse contexto as empresas passam a rever sua atuação. Seja por pressão social ou consciência descobrem que outro interesse, além do lucro e a satisfação de seus acionistas, devem ser considerados e passam a seguir os preceitos de responsabilidade social. Conforme 0 Instituto Ethos de Empresas e Responsabilidade Social:

\footnotetext{
Responsabilidade social é uma forma de conduzir os negócios da empresa de tal maneira que a torna parceira e co-responsável pelo desenvolvimento social. A empresa socialmente responsável é aquela que possui a capacidade de ouvir os interesses das diferentes partes (acionistas, funcionários, prestadores de serviços, fornecedores, consumidores, comunidade, governo e meio ambiente) e conseguir incorporá-los no planejamento de suas atividades, buscando atender às demandas de todos e não apenas dos acionistas ou proprietários. (Instituto Ethos, 2003)
}

O enfoque deste trabalho esta na dimensão interna da responsabilidade social, onde a empresa socialmente responsável busca atender as demandas de seus 
funcionários. Elas entendem que a valorização do capital humano e a qualidade de vida no trabalho tornaram-se questões estratégicas que promovem o aumento do poder competitivo para as organizações que buscam se destacar no mercado.

Nas últimas décadas os avanços tecnológicos proporcionaram o surgimento de novas formas de organização do trabalho. As empresas em busca de alternativas que promovam o envolvimento da força de trabalho aos interesses do capital entendem que maior produtividade e competitividade não devem comprometer a qualidade de vida de seus trabalhadores. Segundo Lipp (1996) o conceito de qualidade de vida pode ser entendido como:

[...] o viver que é bom e compensador em pelo menos quatro áreas: social, afetiva, profissional e a que se refere à saúde. Para que a pessoa possa ser considerada como tendo uma boa qualidade de vida, torna-se necessário que ela tenha sucesso em todos esses quadrantes. Não adianta você ter muito sucesso só na carreira, ou só na área social e não ter nas outras áreas (LIPP, 1996, p. 42).

O universo corporativo já sabe reconhecer que o diferencial do negócio tem por base o ser humano. A preocupação com os colaboradores deve ir muito além do desenvolvimento dos profissionais e de uma oferta atrativa de remuneração.

[...] para alcançar qualidade e produtividade, as organizações precisam ser dotadas de pessoas participantes e motivadas nos trabalhos que executam e recompensadas adequadamente por sua contribuição. Assim a competitividade organizacional passa obrigatoriamente pela qualidade de vida no trabalho. Para atender o cliente externo, não se deve esquecer o cliente interno. Para conseguir satisfazer o cliente externo, as organizações precisam antes satisfazer seus funcionários responsáveis pelo produto ou serviço oferecido (CHIAVENATO, 2000, p. 295).

A partir desta pesquisa buscamos evidenciar a percepção dos colaboradores internos, de uma instituição bancária nacional, em uma de suas unidades, quanto à efetividade do Programa de Qualidade de Vida no trabalho - QVT. 
O programa foi implantado pela empresa como prática de responsabilidade social e busca promover a melhoria da qualidade de vida no trabalho. Para tanto escolhemos o estudo de caso único com abordagem quantitativa descritiva com a aplicação de um questionário composto de 10 questões fechadas.

Este trabalho nos permitiu concluir que os colaboradores internos, na unidade da instituição bancária pesquisada têm um grau satisfatório de conhecimento a cerca do conceito responsabilidade social, pois demonstram muito interesse pelo tema e buscam atualizarem-se constantemente dentro e fora da empresa. No entanto demonstraram incerteza quanto à efetividade do programa QVT adotado pela empresa, que por motivos diversos não foi implementado plenamente naquela unidade.

A instituição financeira brasileira de economia mista, a qual, em virtude de não conseguirmos autorização expressa da empresa em tempo hábil à apresentação deste trabalho, se intitulará Banco Nacional S.A., por meio de sua unidade operacional denominada Setor Risco União, sediada em Brasília - DF é o cenário desta pesquisa. 


\section{Formulação do problema}

Alguns autores trazem a idéia de que as empresas consomem recursos naturais que estariam vinculados direta ou indiretamente a um patrimônio que não lhes pertence, pois sendo de direito coletivo pertencem à sociedade em geral, devendo assim prestar contas à sociedade sobre a eficiência do uso destes recursos. Nesta perspectiva a Responsabilidade Social se manifesta em duas dimensões: a do público interno e a do público externo.

$\mathrm{Na}$ dimensão interna o comprometimento espontâneo dos empregados e o trabalho em equipe são perseguidos pelas empresas que reconhecem o capital humano como aliado em busca de maior competitividade no mercado.

Assim, dentro dos preceitos da Responsabilidade Social, o empregador oferece aos seus funcionários além da simples compensação financeira, benefícios como: planos de saúde, contratação de transporte, reconhecimento intelectual e pessoal, além de outras ações institucionais que visam promoção da qualidade de vida.

O Banco Nacional S/A imbuído de caráter sócio responsável, adotou uma série de ações institucionais voltadas aos seus colaboradores internos, dentre elas o Programa de Qualidade de Vida no Trabalho - QVT, que tem por objetivo promover a melhoria da qualidade de vida no trabalho, a partir da promoção do estilo de vida saudável.

De posse destas informações e estimulado pelo universo acadêmico ao exercício da pesquisa, o formando que faz parte do quadro funcional do Banco Nacional S/A e observando seu próprio ambiente de trabalho formulou o seguinte questionamento: Os colaboradores internos vinculados a unidade Risco União - DF do Banco Nacional S/A reconhecem o Programa Qualidade de Vida no Trabalho - QVT, adotado pela empresa como uma prática, sócio responsável de caráter interno, efetiva? 


\section{Objetivos}

\subsection{Objetivo Geral}

O foco de desenvolvimento deste trabalho consiste em:

- Avaliar a efetividade do programa QUALIDADE DE VIDA NO TRABALHO - QVT, adotado por uma instituição bancária brasileira de economia mista, na percepção dos colaboradores internos de uma de suas unidades operacionais.

\subsection{Objetivos Específicos}

Neste item abordamos as etapas e os focos de desenvolvimento parcial do trabalho, definidos com o intuito de alcançar o objetivo geral desta pesquisa. Assim temos como objetivos específicos:

- Identificar o grau de familiaridade dos colaboradores internos ao tema responsabilidade social e ao programa QVT;

- Caracterizar o Programa de Qualidade de Vida, na definição da empresa; 


\section{Justificativa}

Responsabilidade Social é um conceito de extrema relevância e que está presente no dia a dia das organizações modernas. Por motivações diversas, estas empresas buscam rever e aprimorar a aplicação deste conceito em sua cultura organizacional, retribuindo os benefícios recebidos às comunidades com que operam.

No estudo das ciências administrativas podemos observar a evolução do conceito de capital humano e sua importância como vantagem competitiva para as organizações, o que é suportado por inúmeros autores, como Pfeffer, (1994 apud JONAS, 2008, p3) segundo o qual:

A percepção pelos empregados de que no local de trabalho existe potencial para satisfação de suas necessidades psicológicas, gera maior comprometimento, entusiasmo e dedicação ao trabalho e, em conseqüência, maior produtividade para a organização, sendo a capacidade, o conhecimento e o comprometimento os grandes diferenciais para as organizações.

No conceito de responsabilidade social encontramos a idéia de pluralidade que sob um enfoque sistêmico se traduz em parceria onde, para além da coabitação, deve existir a interdependência entre colaboradores e corporação em busca do sucesso mútuo.

A partir desta linha de pensamento imaginamos contribuir, por meio desta pesquisa, evidenciando a percepção dos colaboradores internos de uma instituição bancária nacional, em relação à efetividade do Programa de Qualidade de Vida no trabalho QVT uma das práticas Sócio Responsáveis, de caráter interno, adotada pela empresa. E, também, aprimorar os conhecimentos adquiridos durante o período acadêmico, bem como, cumprir com a exigência parcial para a conclusão do curso de administração. 


\section{Caracterizações da organização}

Fundada em 12 de outubro de 1808, a instituição bancária, onde realizamos nossa pesquisa é a mais antiga e também considerada o maior, no âmbito Nacional. Com o advento da globalização, as empresas brasileiras foram forçadas a empreender mudanças no modo de gerir seus negócios, a fim de garantir sua manutenção no mercado.

Em 1986, com a extinção da conta-movimento, o Banco passou por sua maior transformação, perdendo o controle de algumas funções de política monetária, transferidas para o Banco Central do Brasil - BC. Esta situação o levou à independência no mercado, acarretando a perda de privilégios junto ao Governo Federal e passando, então, a poder praticar quaisquer operações cabíveis às instituições financeiras.

Assim, o Banco buscou novos caminhos que pudessem alavancar a sua atuação comercial, tornando-o mais competitivo no mercado. Embora a empresa tivesse quase dois séculos de história, essa experiência não foi suficiente para mantê-la nesse mercado, o que a levou a buscar novas atitudes e estratégias de atuação.

Atualmente, conforme o seu Relatório Anual e de Responsabilidade Socioambiental $^{1}$, a empresa julga que seu diferencial está na "capacidade de atender todos os segmentos do mercado, com produtos, serviços e soluções em negócios, sem descuidar do papel social de fomentador de programas, projetos e iniciativas que reafirmam os mais autênticos valores brasileiros."

O relacionamento com os diferentes públicos está fundamentado na Carta de Princípios e Responsabilidade Socioambiental e nos princípios éticos expressos no Código de Ética e Normas de Conduta Profissional do Banco Nacional.

\footnotetext{
${ }^{1}$ Relatório Anual e de Responsabilidade Socioambiental 2009 Banco do Brasil. p. 13 Disponível em <HTTP:/WWW.bb.com.br>
} 
Quanto ao posicionamento da marca, pretende reunir atributos não negociais, ou simbólicos, que representem o quadro de valores associados à Instituição. Para a empresa $^{2}$ "esse posicionamento deverá sinalizar a identidade com o cliente, agregando atributos como tradição, brasilidade e alcance geográfico e social de atuação." Por meio do conceito de identidade buscará o fortalecimento dos vínculos afetivos entre empresa e públicos.

\subsection{Princípios Éticos e Socioambientais do Banco Nacional S/A}

A postura de responsabilidade socioambiental do Banco Nacional tem como premissa a crença na viabilidade de se conciliar o atendimento aos interesses dos seus acionistas com o desenvolvimento de negócios social e ecologicamente sustentáveis, mediante o estabelecimento de relações eticamente responsáveis com seus diversos públicos de interesse, interna e externamente.

Vai além, acredita que esta postura contribua para o desenvolvimento de um novo sistema de valores para a sociedade que tenha como referencial maior o respeito à vida humana e ao meio ambiente, condição indispensável à sustentabilidade da própria humanidade.

Esses compromissos, definidos pelo Conselho Diretor e pelo Conselho de Administração do Banco Nacional e assumidos por toda a organização, estão expressos na Carta de Princípios de Responsabilidade Socioambiental e no Código de Ética do Banco Nacional.

\footnotetext{
${ }^{2}$ Relatório Anual e de Responsabilidade Socioambiental 2009 Banco do Brasil. p. 13 Disponível em <HTTP:MWWW.bb.com.br>
} 


\subsection{Carta de Princípios de Responsabilidade Socioambiental do banco Nacional S/A}

Conforme informações disponíveis no site da empresa, O Banco Nacional se compromete a:

- Atuar em consonância com Valores Universais, tais como: Direitos Humanos, Princípios e Direitos Fundamentais do Trabalho, Princípios sobre Meio Ambiente e Desenvolvimento.

- Reconhecer que todos os seres são interligados e toda forma de vida é importante.

- Repelir preconceitos e discriminações de gênero, orientação sexual, etnia, raça, credo ou de qualquer espécie.

- Fortalecer a visão da Responsabilidade Socioambiental como investimento permanente e necessário para o futuro da humanidade.

- Perceber e valer-se da posição estratégica da corporação, nas relações com o Governo, o Mercado e a Sociedade Civil, para adotar modelo próprio de gestão da Responsabilidade Socioambiental à altura da corporação e dos desafios do Brasil contemporâneo.

- Ter a transparência, a ética e o respeito ao meio ambiente como balizadores das práticas administrativas e negociais da Empresa.

- Pautar relacionamentos com terceiros a partir de critérios que observem os princípios de responsabilidade socioambiental e promovam o desenvolvimento econômico e social.

- Estimular, difundir e implementar práticas de desenvolvimento sustentável.

- Enxergar clientes e potenciais clientes, antes de tudo, como cidadãos.

- Estabelecer e difundir boas práticas de governança corporativa, preservando os compromissos com acionistas e investidores.

- Contribuir para que o potencial intelectual, profissional, artístico, ético e espiritual dos funcionários e colaboradores possa ser aproveitado, em sua plenitude, pela sociedade.

- Fundamentar o relacionamento com os funcionários e colaboradores na ética e no respeito.

- Contribuir para a universalização dos direitos sociais e da cidadania.

- Contribuir para a inclusão de pessoas com deficiência. 


\subsection{Código de Ética do Banco Nacional S/A}

Atualmente observa-se que a gestão da ética corporativa, além de comportar a tradicional visão filosófica do tema, a qual em essência busca discernir o que é bom do que é mau, também se relaciona - pragmaticamente - com a tríade de sustentabilidade (social, ambiental e econômica), com a imagem da empresa, exigências de stakeholders, obtenção de certificações e, no limite, com a ampliação da capacidade das organizações realizarem negócios e gerar resultados.

Neste contexto, os códigos de ética representam o marco fundamental de qualquer programa de gestão da ética corporativa, pois explicitam os valores ou referenciais éticos que devem orientar o comportamento dos funcionários e o da própria organização.

O Código de Ética do Banco Nacional foi atualizado no segundo semestre de 2009. $\mathrm{Na}$ construção deste documento foram referenciados os preceitos éticos considerados importantes pela empresa, as recomendações da Organization for Economic Co-operation and Development, da Comissão de Ética Pública da Presidência da República, Indicadores Ethos de Responsabilidade Social, Índice Dow Jones de Sustentabilidade, Lei Sarbanes-Oxley e Índice de Sustentabilidade Empresarial da IBOVESPA. Também foram ouvidos empregados e estagiários; clientes; fornecedores; entidades sindicais; acionistas e analistas de mercado, cujas sugestões foram agregadas ao texto final.

De acordo com os valores que expressam, o Código de Ética da empresa agrega nove perspectivas: clientes, funcionários e colaboradores, fornecedores, acionistas, investidores e credores, parceiros, concorrentes, governo, comunidade e órgãos reguladores.

Além dos normativos internos relacionados à ética corporativa, os executivos da empresa também estão submetidos ao Código de Conduta da Alta Administração federal. 


\section{REFERENCIAL TEÓRICO}

\subsection{Responsabilidade Social}

Responsabilidade social, segundo Ashley (2003) ainda é um conceito em construção, mas que pode ser interpreado como um compromisso assumido pelas instituições junto a sociedade onde se inserem, e que pode ser expresso por meio de práticas que afetam de forma positiva, abrangentendo-a amplamente, ou a alguma comunidade, de modo específico, de maneira proativa e etica no que diz respeito a sua função social e a sua prestação de contas para com ela.

Ainda, conforme Ashley (2003) as instituições assumem responsabilidades de caráter moral, extrapolando as determinações legais, mesmo que indiretamente ligadas às suas atividades, mas que possam de alguma forma trazer benefícios às comunidades. Desta forma, numa compreenção mais ampla, o conceito de responsabilidade social abrange as práticas que contribuam para o desenvolvimento social gerando melhorias e qualidade de vida na sociedade.

Esta definição de responsabilidade social indica que as empresas devem assumir um novo papel perante sociedade, extrapolando o âmbito do mercado, e como agente autônomo no seu interior, imbuído de deveres e obrigações que saem do âmbito econômico. A empresa é vista cada vez mais como um sistema social organizado em que se desenvolvem diversas relações, além das estritamente econômicas. Afirma Dias (2008). 


\subsection{Responsabilidade Social: Interna e externa}

As empresas podem atuar com responsabilidade social em dois níveis: externamente ou internamente.

Conforme Melo Neto e Fróes (1999) a gestão da responsabilidade social interna tem como principal característica ser o primeiro estágio da cidadania empresarial. Seu foco esta no público interno da instituição. Presume desenvolver um modelo de gestão participativa, com reconhecimento de seus colaboradores, condições de trabalho adequadas, remuneração justa, bom clima organizacional, comunicação transparente e níveis de motivação elevados; o que resulta conseqüentemente em um desempenho melhor. Envolve também a preocupação com a qualidade de vida dos empregados e seus dependentes, contratados, terceirizados, parceiros e fornecedores.

A responsabilidade social externa consiste em ações sociais que proporcionem o bem estar da comunidade e de todos os segmentos relacionados com a empresa. $A$ promoção de ações sociais, mesmo que direcionadas a segmentos que não se relacionam com a empresa como: programas culturais, doações a entidades filantrópicas, reflorestamentos, entre outras podem também fazer parte do composto que caracteriza uma empresa como responsável socialmente.

No entanto estas ações realizadas de forma isolada e sem vínculos, comprometimento e continuidade podem ser classificadas apenas como ações filantrópicas (MELO NETO; FROES, 1999).

Muitas empresas têm concentrando esforços no âmbito externo da responsabilidade social em busca da valorização de sua marca e melhoria da impressão deixada por sua imagem. Segundo especialistas estas empresas estão na contramão do processo, pois, muitas vezes preocupadas apenas com a imagem, falham em relação aos seus principais colaboradores, podendo gerar insatisfação interna. 
O descontentamento sistemático repercute em todas as ações da empresa, resultando em baixa produtividade, falta de qualidade, aumento do índice de absenteísmo e, não raro, na perda de profissionais qualificados atraídos para suas concorrentes mais atentas a estes aspectos.

Quando falamos em perda de profissionais qualificados, é possível que não se faça uma relação com o fato de que a empresa seja ou não socialmente responsável, porém uma pesquisa realizada pela You \& Company com cerca de 2000 estudantes de cursos de especialização em gerenciamento (MBA - Master Business Administration) revelou que mais de $50 \%$ deles prefeririam trabalhar em companhias éticas, mesmo que isso significasse salários menores (ASHLEY, 2002).

Desta forma, torna-se primordial uma reflexão, por parte das empresas acerca do tema responsabilidade social.

\subsection{Responsabilidade Social ou Filantropia}

Atualmente a filantropia é um das ações que tem contribuído de forma significante na solução de problemas sociais, porque de uma forma imediata tem amenizado dificuldades e ajudado diversos segmentos da sociedade que por motivos diversos não são tendidas suficientemente pelo Estado. No entanto, muitos empresários ao desenvolverem atividades filantrópicas entendem ou querem acreditar que estão sendo socialmente responsáveis.

A diferença básica entre filantropia e responsabilidade social pode ser entendida conforme a definição do Insthituto Ethos, segundo o qual:

A filantropia é basicamente uma ação social externa da empresa que tem como beneficiária principal a comunidade em suas diversas formas (conselhos comunitários, organizações não-governamentais, associações 
comunitárias etc.) e organizações. A responsabilidade social é focada na cadeia de negócios da empresa e engloba preocupações com um público maior (acionistas, funcionários, prestadores de serviço, fornecedores, consumidores, comunidade, governo e meio ambiente), cuja demanda e necessidade a empresa deve buscar entender incorporar aos negócios. Assim, a responsabilidade social trata diretamente dos negócios da empresa e de como ela os conduz. (INSTITUTO ETHOS, 2007)

Em momento algum se acredita que deva extinguir a filantropia de nossa sociedade, entende-se sim, que é preciso atuar de forma a possibilitar a continuidade dos esforços para que as causas dos problemas sejam tratadas e que as ações desenvolvidas resultem em melhoria de condições e solução dos problemas.

\subsection{Responsabilidade Social Empresarial}

Por tratar-se de um conceito em construção a maioria das definições que encontramos trata da responsabilidade social corporativa ou empresarial. No entanto, o assunto pode e deve ser tratado de forma muito mais abrangente, pois cada habitante do planeta é responsável pela sobrevivência da humanidade.

No início, a responsabilidade social empresarial era voltada apenas para atendimento das necessidades e retorno aos proprietários e acionistas. O crescimento das atividades voltadas para as causas sociais e a descoberta de que a atuação socialmente responsável se tornou um grande diferencial competitivo, capaz de manter e promover a imagem da empresa no mercado ampliou significativamente a atuação das empresas. Elas passaram a se preocupar também com os stakeholders que, segundo Martins (2005 Apud Freeman, 1984, p. 46), é "qualquer grupo ou indivíduo que pode afetar ou ser afetado pelo cumprimento dos objetivos da organização". 
De acordo com Ashley (2002) para cada segmento que compõem os stakeholders de uma organização a responsabilidade social empresarial tem um direcionamento e uma visão específica. O cumprimento ou não de cada direcionamento deste é que vai possibilitar uma avaliação da empresa quanto a sua atuação ser ou não responsável socialmente. Em relação ao segmento dos acionistas, afirma Ashley, a orientação é no sentido de maximização dos lucros em uma visão econômica.

Sendo assim, compreendia-se que a única meta das instituições deveria ser a busca pela maximização do retorno financeiro aos seus proprietários (Ashley, 2002). Uma grande mudança se deu quando outros públicos ligados ou afetados pela empresa e suas atividades passaram a ser considerados. Mesmo tendo, cada segmento, conforme avalia Ashley (2002), um direcionamento específico, o entrelaçamento e a união de todas as visões abordadas podem resultar em um comportamento socialmente responsável por parte da empresa.

\section{MÉTODOS E TÉCNICAS DE PESQUISA}

O objetivo geral, deste trabalho, buscou verificar a percepção dos funcionários em uma das unidades do Banco Nacional S/A quanto à efetividade de uma das praticas, de caráter sócio responsável, voltada ao público interno. Para tanto escolhemos o estudo de caso como método de pesquisa

Segundo Acevedo e Nohara (2009), estudo de caso se caracteriza pela análise em profundidade de um objeto ou grupo de objetos, que podem ser indivíduos ou organizações. O estudo de caso como estratégia de pesquisa é um método que compreende o planejamento, as técnicas de coleta de dados e as abordagens de análise dos dados. É um delineamento que se preocupa com questões do tipo "como" e "por que" que focaliza acontecimentos contemporâneos e não exige controle sobre eventos comportamentais. Assim como outras estratégias de 
pesquisa, o estudo de caso é uma forma de investigar um assunto seguindo-se um conjunto de procedimentos predeterminados.

Já em Yin (1994; 2005) o estudo de caso é conceituado como estudo empírico que investiga um fenômeno atual dentro do seu contexto de realidade, quando as fronteiras entre o fenômeno e o contexto não são claramente definidas e no qual são utilizadas várias fontes de evidência. Yin (1994; 2005) ainda afirma que o estudo de caso tanto pode trabalhar com evidências qualitativas ou quantitativas, não requerendo necessariamente um modo único de coleta de dados, podendo também ter dois tipos de variantes que são: estudo de caso único e estudo de caso múltiplo.

Para este trabalho foi realizado um estudo de caso único com abordagem quantitativa descritiva com a aplicação de um questionário composto de 10 questões fechadas.

Quanto à abordagem, optamos pela quantitativa descritiva que conforme Roesch (2009) tem por objetivo obter informações sobre uma população ou um levantamento de atitudes dentro de uma organização. Para Hair et al. (2005) as pesquisas descritivas geralmente são realizadas para medir as características descritas em uma questão de pesquisa, por exemplo, quanto à satisfação ou não de um grupo pesquisado em relação a um tema proposto.

\subsection{População e amostra do estudo}

O Centro de Serviços Operacionais - CSO RISCO UNIÃO DF, situado em Brasília (DF), cujo quadro funcional não foi totalmente definido pela empresa e, por conta disso, a pesquisa foi direcionada tão somente aos 72 Assistentes nomeados até então. Estes funcionários são público alvo do programa QVT e constituem o primeiro 
escalão de comissionados, cuja jornada de trabalho é 40h semanais, sendo que estes passam 1/3 de seu tempo diário no ambiente da empresa.

Destes 72 funcionários apenas 60 formam a amostra, ou participantes do trabalho, 0 que nos permite um Intervalo de confiança de aproximadamente 95\%.

\subsection{Caracterização dos instrumentos de pesquisa}

Como instrumento de coleta de dados foi utilizado um questionário com questões fechadas cujas respostas foram baseadas na escala de Lickert. Conforme afirmação de Malhotra (2001) a escala Likert é uma escala de classificação amplamente utilizada, que exige que os entrevistados indiquem um grau de concordância ou discordância com cada afirmativa das questões e são baseadas em seis níveis que variam entre Discordância e Concordância, plenas.

O questionário teve aplicação presencial, pelo formando, em material impresso, no dia 24 do mês de setembro de 2010, na unidade escolhida do Banco Nacional, o Centro de Serviços Operacionais - CSO RISCO UNIÃO DF, situado em Brasília (DF), cujo quadro funcional não foi totalmente definido pela empresa e, por conta disso, direcionamos a pesquisa tão somente aos 72 funcionários da carreira de Assistente A.

\subsection{Procedimentos de coleta e de análise de dados}

Foi realizado um estudo de caso único com abordagem quantitativa descritiva com a aplicação de um questionário composto de questões fechadas. Conforme Roesch (2009), questionário não é apenas um formulário ou um conjunto de questões listadas sem muita reflexão.

O questionário é um instrumento de coleta de dados que busca mensurar alguma coisa. Para tanto, requer esforço intelectual anterior ao planejamento, com base na 
conceituação do problema de pesquisa e do plano de pesquisa. O passo seguinte é elaborar uma lista abrangente de cada variável a ser medida e a maneira como será operacionalizada, ou seja, por meio de escalas, questões abertas ou fechadas, etc.

Quanto à abordagem, elegemos uma abordagem quantitativa descritiva que conforme Roesch (2009) tem por objetivo obter informações sobre uma população ou um levantamento de atitudes dentro de uma organização. Para Hair et al. (2005) as pesquisas descritivas geralmente são realizadas para medir as características descritas em uma questão de pesquisa, por exemplo, quanto à satisfação ou não de um grupo pesquisado em relação a um tema proposto.

A apuração dos resultados, que subsidiam as análises e conclusões finais, foi estratificada por meio de um software, o EXCEL e demonstrados em gráficos e tabelas na forma proporcional de percentagens com a utilização da técnica de distribuição de freqüência que, conforme Aaker (2001), as estatísticas descritivas geralmente estão associadas à distribuição de freqüência ajudando a sumarizar as informações. Para o autor a tabulação de dados torna-se facilitada por meio da distribuição de freqüência que resulta no número de respostas recebidas por cada questão.

O questionário contempla 10 itens, sob a forma de frases afirmativas, onde coube a cada respondente assinalar seu grau de concordância ou discordância em relação ao enunciado, de acordo com a seguinte escala: 1-Discordo Totalmente; 2- Discordo Muito; 3-Discordo Pouco; 4-Concordo Pouco; 5-Concordo Muito; e 6- Concordo Totalmente. 


\section{RESULTADOS E DISCUSSÃO}

Neste capítulo no primeiro momento descrevemos as características do programa QVT, segundo as informações da própria empresa. Em seguida apresentamos os resultados da pesquisa efetuada junto aos funcionários do Banco Nacional em relação à sua percepção sobre a efetividade do Programa de Qualidade de Vida no Trabalho - QVT, enquanto ação sócio responsável, de caráter interno, adotada pela empresa.

\subsection{Caracterizações do Programa QVT do Banco Nacional S.A.}

O Programa foi adotado pela empresa como prática de responsabilidade social e tendo por objetivo promover a melhoria da qualidade de vida no trabalho, a partir da promoção de estilo de vida saudável e tem como público alvo todos os funcionários, estagiários e adolescentes trabalhadores

O programa é uma ação institucional e tem como pressupostos:

- A adesão a qualquer atividade integrante do Programa é voluntária;

- Considera a diversidade do público em suas variações culturais, diferenças regionais e interesses coletivos;

- A educação continuada é o caminho para adoção de estilo de vida saudável;

- A responsabilidade pelos cuidados com a saúde e a segurança no trabalho é compartilhada entre Empresa, funcionários, estagiários e adolescentes trabalhadores.

O programa oferece vários benefícios ao público interno da empresa, dentre eles a Verba QVT que se destina ao pagamento de empresas ou profissionais autônomos que conduzam práticas antiestresse e atividades devem ser escolhidas de modo a contribuir para a melhoria do clima organizacional e da satisfação dos trabalhadores. 
Segundo o programa QVT são consideradas práticas antiestresse aquelas que visam à promoção da saúde e da qualidade de vida no trabalho. As práticas antiestresse definidas para o ambiente de trabalho são: ginástica laboral, relaxamento, alongamento, eutonia, ioga, liang gong, taichi chuan, pilates, dança de salão, dança circular e massagem expressa.

A gestão dos recursos disponibilizados é participativa, ou seja, funcionários, estagiários e aprendizes participam da escolha das práticas antiestresse a serem contratadas.

A realização das práticas antiestresse deve ocorrer de forma regular e sistemática. Atividades pontuais ou concentradas em um único mês não garantem benefícios efetivos no controle dos níveis de estresse.

As práticas devem ser realizadas em horários que possibilitem a participação do maior número de pessoas, sendo vedada a utilização da Verba QVT em eventos que não tenham a participação da maioria dos funcionários, estagiários e aprendizes da dependência.

A adesão às práticas antiestresse é voluntária, respeitando a disponibilidade e o interesse pessoal de cada participante.

As dependências devem estimular a diversificação das práticas oferecidas para possibilitar aos participantes experimentarem diferentes modalidades de atividades antiestresse.

As práticas antiestresse devem ser realizadas no ambiente de trabalho, durante 0 expediente e em horário não coincidente com o do atendimento ao público, exceção feita à massagem expressa que, por ser uma atividade individual, pode ser realizada no horário de atendimento ao público. O tipo de evento e os horários devem ser previamente negociados com o comitê de administração da dependência e realizados com a concordância do mesmo.

As práticas de caráter coletivo podem ser realizadas em grupos de até 25 funcionários, em, no máximo, 04 sessões semanais de até 15 minutos ou em 02 sessões semanais de até 30 minutos. No caso da massagem expressa, prática de 
caráter individual, é permitida uma sessão semanal de até 15 minutos.

Uma vez por ano a empresa promove a Semana QVT, realizada rede Gestão de pessoas, que o objetivo de desenvolver ações para fortalecer a cultura da saúde, do bem estar e da qualidade de vida.

A proposta de programação da Semana QVT atende às seguintes premissas:

a) Privilegiar ações que tenham caráter educativo, integrativo, motivador e vivencial e que estimulem a adoção de mudanças no estilo de vida;

b) Contemplar iniciativas que alcancem o maior número possível de funcionários, estagiários e aprendizes BB;

c) Evitar atividades que concorram ou comprometam o atendimento a clientes;

d) Desenvolver iniciativas diversificadas que contemplem peculariedades regionais

e) Priorizar fornecedores e parceiros comprometidos com a questão da sustentabilidade e que apresentem o menor preço;

f) Utilizar insumos (papel, água, energia, plástico e outros) de forma planejada visando evitar desperdícios;

g) Planejar ações considerando o Código de Ética e a Carta de Princípios de RSA do Banco

A Verba QVT é alocada anualmente pela empresa e obedece aos seguintes critérios:

- $R \$ 15,00$ mensais por funcionário em agências;

- $R \$ 10,00$ mensais por funcionário na Rede de Apoio aos Negócios e à Gestão e na Direção Geral;

- $\mathrm{R} \$ 10,00$ mensais por estagiários ou adolescentes trabalhadores localizados tanto em agências como na Rede de Apoio aos Negócios e à Gestão e na Direção Geral;

O valor orçado no mês pode ser utilizado no mês seguinte, desde que as práticas antiestresse tenham sido realizadas e que o pagamento não tenha sido efetuado ou provisionado e a verba QVT não pode ser utilizada na forma de ressarcimento a funcionários, estagiários e aprendizes. 
A contratação e pagamento de empresa/profissional autônomo devem ser realizados no âmbito da própria dependência e os valores utilizados com pagamento de serviços de QVT impactam o limite da dependência para as despesas de pequeno vulto conforme parâmetros abaixo:

- $\quad$ o valor da contratação não deve ser superior a $R \$ 4.000,00$;

- Sejam observadas as normas desta Instrução, em especial aquelas relativas À Dispensa de licitação por limite de valor

- A contratação do contribuinte individual (autônomo), aposentado ou não, deve ser feita com prestador de serviço regularmente inscrito no Regime de Previdência Social, comprovado mediante a apresentação do NIT - Número de Inscrição do Trabalhador no INSS. Este dado (NIT) pode ser substituído pelo número da inscrição do profissional no PIS ou Pasep.

- O documento comprobatório da regularidade do trabalhador perante o INSS como contribuinte individual (NIT ou PIS ou Pasep) deve ser obtido antes de sua contratação e arquivado junto ao processo para subsidiar informações ao INSS, em eventual fiscalização.

- As contratações que exigem formalização de contrato devem ser conduzidas, obrigatoriamente, pelo Centro de Serviços e Logística - CSL.

O Gerenciamento dos Recursos destinados ao programa QVT está a cargo da Equipe de Comunicação e Autodesenvolvimento - ECOA que deve ouvir os funcionários, estagiários e aprendizes sobre suas necessidades e preferências e decidir, quando não for possível atender a todos, pelas atividades que contemplem o interesse da maioria. A ECOA deverá divulgar, aos funcionários, e colaboradores, o planejamento anual das ações de QVT. 


\section{A percepção dos funcionários}

Antes da aplicação oficial do questionário à totalidade de colaboradores, realizamos um pré-teste das questões com 05 funcionários do setor quando então verificamos itens pertinentes ao preenchimento correto. Avaliamos o tempo estimado, bem como o grau de dificuldade da interpretação das questões.

Para caracterizarmos os participantes do estudo indagamos sobre o gênero, faixa etária, tempo de empresa e grau de instrução. Abaixo seguem os resultados.

A tabela 01 apresenta a caracterização da população por meio do indicador gênero:

01. GÊNERO

\begin{tabular}{lr|rc}
\hline & & \multicolumn{1}{c}{ Total } \\
MASCULINO & & $49 \%$ & 29 \\
FEMININO & & $51 \%$ & 30 \\
& & & \\
\hline Análise técnica & 1,508 & Conclusões destacadas \\
Média & A opção mais escolhida foi "FEMININO". \\
Intervalo de confiança (95\%) & {$[\mathbf{1 , 3 8 0}-\mathbf{1 , 6 3 7 ]}$} & \\
Tamanho da amostra & $\mathbf{5 9}$ & \\
Desvio padrão & $\mathbf{0 , 5 0 4}$ & A opção menos escolhida foi "MASCULINO". \\
Erro amostral & $\mathbf{0 , 0 6 6}$ & \\
\hline
\end{tabular}

Tabela 01 - Gênero/análise técnica

Fonte - Elaborada pelo formando.

Podemos observar na tabela 01 que 29 participantes são do gênero masculino, que corresponde a $49,15 \%$ dos questionados e 30 participantes são do gênero feminino, que corresponde a $50,85 \%$ da população abordada, sendo que apenas um não respondeu. 
$\mathrm{Na}$ seqüência apresentamos a tabela 2, referente à faixa etária da população da pesquisa.

\section{2 - FAIXA ETÁRIA}

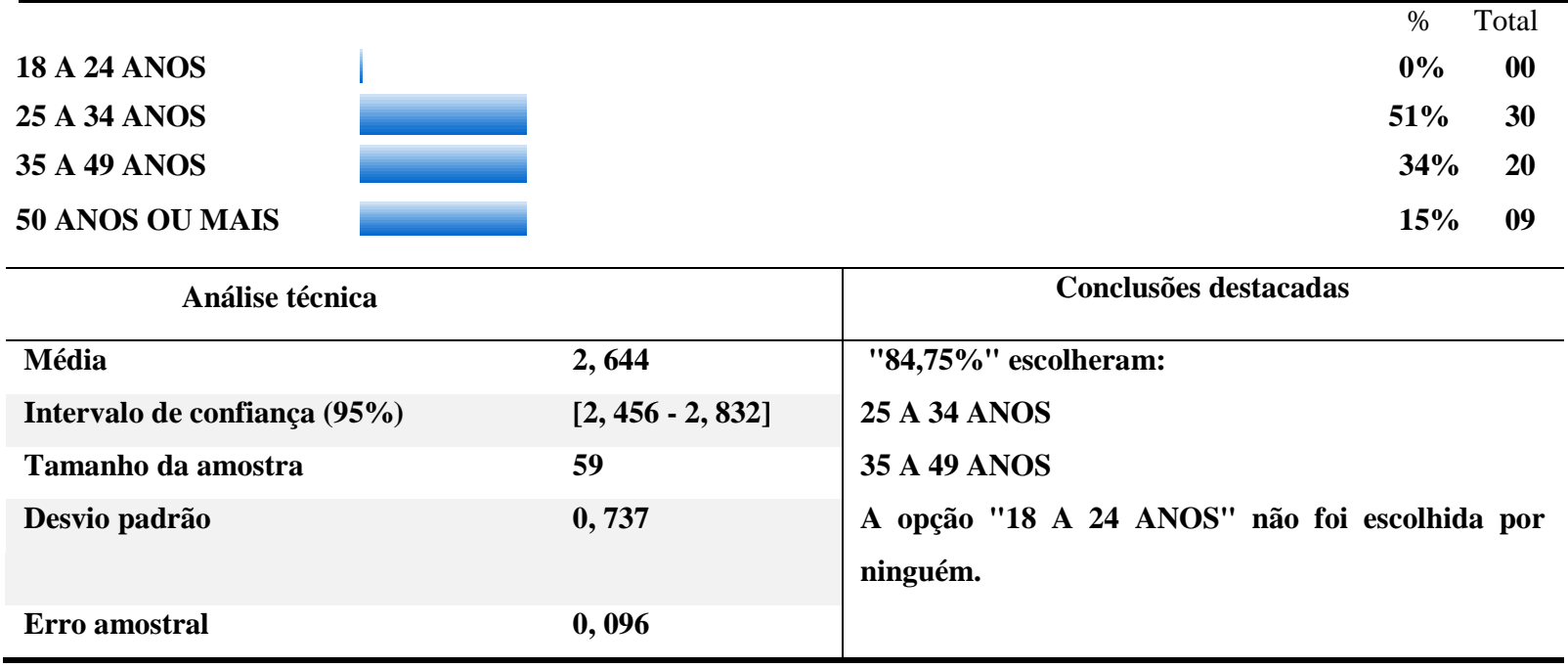

Tabela 02 - Faixa etária/análise técnica / Fonte - Elaborada pelo formando.

Temos na tabela 2 que 30 participantes têm idade entre 25 e 34 anos, o que corresponde a $51 \%$ dos questionados e outros 20 ou $34 \%$ estão entre os 35 e 49 anos, caracterizando a faixa etária baixa com tendência para média no quadro de funcionários do setor, onde apenas 09 funcionários têm 50 anos ou mais, correspondendo a 15\% e nenhum abaixo dos 24 anos confirmando assim a média de idade entre os funcionários do Setor.

A pesquisa foi direcionada apenas aos funcionários com cargo de assistente $A$, que é o nível básico do setor e representa $85 \%$ do seu quadro funcional. Por tratar-se de um setor novo e que centraliza o tipo de serviço executado, sendo que a concorrência aos cargos teve âmbito nacional, verificamos a origem geográfica dos colaboradores, não tendo, no entanto, se mostrado um dado relevante para esta pesquisa. Como apresentado na tabela a seguir: 


\begin{tabular}{lcc}
\hline 03- Em que região do país você morava, antes de vir trabalhar em Brasília - DF & \multicolumn{1}{c}{ Total } \\
\hline Região Centro-Oeste & $\mathbf{7 8 \%}$ & $\mathbf{4 6}$ \\
Região Norte & $3 \%$ & $\mathbf{0 2}$ \\
Região Nordeste & $\mathbf{8 \%}$ & $\mathbf{0 5}$ \\
Região Sudeste & $\mathbf{8 \%}$ & $\mathbf{0 5}$ \\
\end{tabular}

Tabela 3 - origem geográfica

Fonte - Elaborada pelo formando.

A tabela 4 apresenta dados relacionados ao tempo de serviço dos questionados.

\begin{tabular}{lcc}
\hline 4. TEMPO NA EMPRESA & $\%$ & Total \\
\hline 00 A 02 ANOS & $8 \%$ & 05 \\
03 A 05 ANOS & $36 \%$ & 21 \\
06 A 09 ANOS & $31 \%$ & 18 \\
10 A 19 ANOS & $12 \%$ & 07 \\
20 A 25 ANOS & $5 \%$ & 03 \\
26 OU MAIS & $8 \%$ & 05
\end{tabular}

Respostas recebidas: 59 /Perguntas sem respostas: 01

Tabela 4 - Tempo em Serviço na Empresa

Fonte - Elaborada pelo formando.

Com relação ao tempo de empresa dos entrevistados, percebemos que 39/60 funcionários possuem menos de 10 anos de trabalho no banco, representando $67 \%$ do total. Cabe destacar que a média da faixa etária observada na tabela 2 pode ter relevante influência neste índice, uma vez que mais da metade do quadro de assistentes do setor têm no máximo 05 anos de trabalho no banco. Apenas 05 funcionários têm mais de 25 anos de banco correspondendo a $08 \%$ do total.

A seguir apresentamos a tabela/gráfico de $n^{\circ} 05$ e a análise técnica, referentes ao grau de escolaridade da população questionada. 
05 - Distribuições da população segundo o grau de escolaridade

\begin{tabular}{|c|c|c|c|}
\hline & & $\%$ & Total \\
\hline NÍVEL MÉDIO & 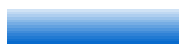 & $15 \%$ & 09 \\
\hline NÍVEL SUPERIOR & 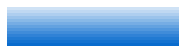 & $59 \%$ & 35 \\
\hline PÓS GRADUAÇÃO & 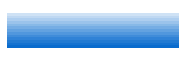 & $25 \%$ & 15 \\
\hline
\end{tabular}

\begin{tabular}{l|r|l} 
Análise técnica & \multicolumn{2}{c}{ Conclusões destacadas } \\
\hline Média & 2,102 & "84,75\%" escolheram: \\
Intervalo de confiança (95\%) & 59 \\
\cline { 1 - 1 } Tamanho da amostra & 0,635 & \multirow{2}{*}{ NÍVEL SUPERIOR } \\
\cline { 1 - 2 } Desvio padrão & 0,083 & \\
\cline { 1 - 2 } Erro amostral & & \\
\hline
\end{tabular}

Tabela 05 - Tempo de serviço/análise técnica

Fonte: Elaborada pelo formando

Quanto ao grau de escolaridade da população pesquisada podemos perceber, conforme apresentado na tabela $n^{\circ} 05$ que 35 questionados possuem formação em nível superior representando $59 \%$ do total da população, sendo que 15 , destes 35 , são pós graduados, o que supostamente indica certa facilidade de compreensão acerca do tema abordado nesta pesquisa.

Findando a etapa de caracterização da população, seguimos a partir da questão número 01, discriminada abaixo, questões relacionadas à familiaridade dos participantes com o conceito de Responsabilidade Social na empresa.

A primeira questão afirma em primeira pessoa o conhecimento sobre o significado do termo responsabilidade social. Obtivemos um resultado significativo, sendo que, dos 60 entrevistados, 76,67\% concordou muito ou pouco que sabiam o que significa responsabilidade social, enquanto que 13 concordaram plenamente com a afirmativa. A partir deste ponto dava-se início às perguntas relativas ao tema do trabalho que se mostrou ser de elevado nível de entendimento por parte dos funcionários já que apenas 01 respondente discordou plenamente da afirmação. 


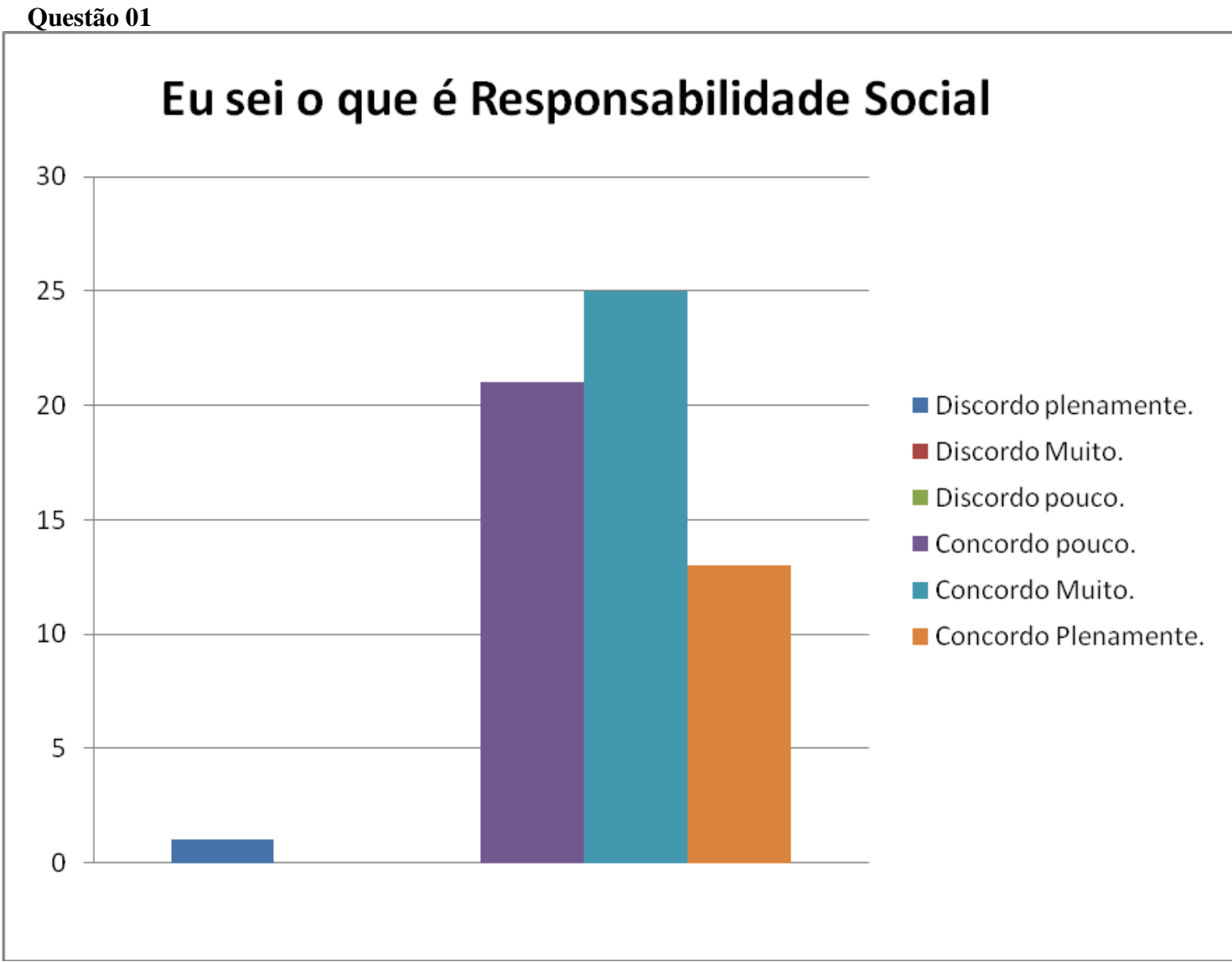

Gáfico 01

Fonte - Elaborado pelo Formando

Análise técnica - População: 60

\begin{tabular}{lr|c}
\hline Eu sei o que é responsabilidade Social. & 4,800 & Conclusões destacadas \\
Média & $74,573-5,027]$ & $\begin{array}{l}\text { Concordo Muito. } \\
\text { Intervalo de confiança (95\%) }\end{array}$ \\
Tamanho da amostra & 60 & $\begin{array}{l}\text { Concordo pouco. } \\
2 \text { opções não foram } \\
\text { escolhidas. }\end{array}$ \\
Desvio padrão & 0,898 & \\
\hline
\end{tabular}

Erro amostral 0,116

Tabela 06 - análise técnica

Fonte - Elaborada pelo formando 
A questão número 02 verificou se os funcionários concordavam que o Programa de Qualidade de Vida no Trabalho - QVT elencado na questão dentre outras práticas implementadas pela empresa correspondia a uma praticas de caráter sócio responsável, sendo que apenas uma das alternativas não se enquadrava no tema. Buscamos assim testar o conhecimento dos colaboradores quanto às desenvolvidas pela empresa, pertinentes ao tema da pesquisa.

\section{A Tabela 07 apresenta o resultado dessa questão.}

07. Resultados - Questão 02 - As práticas listadas abaixo, implantadas pela instituição onde você trabalha, podem ser consideradas ações de responsabilidade social:

\begin{tabular}{|c|c|c|c|c|c|c|c|c|}
\hline & $\begin{array}{l}\text { Discordo } \\
\text { plenamente. }\end{array}$ & $\begin{array}{l}\text { Discordo } \\
\text { Muito. }\end{array}$ & $\begin{array}{l}\text { Discordo } \\
\text { pouco. }\end{array}$ & $\begin{array}{l}\text { Concordo } \\
\text { pouco. }\end{array}$ & $\begin{array}{l}\text { Concordo } \\
\text { Muito. }\end{array}$ & $\begin{array}{l}\text { Concordo } \\
\text { Plenamente. }\end{array}$ & Média & Total \\
\hline $\begin{array}{l}\text { Programa de Qualidade de } \\
\text { Vida no Trabalho - QVT }\end{array}$ & $2 \%(1)$ & $7 \%$ & $5 \%(3)$ & $12 \%(7)$ & $35 \%(21)$ & $40 \%$ & 4,9 & $(60)$ \\
\hline $\begin{array}{l}\text { Venda de seguro de vida e } \\
\text { Crédito Direto ao } \\
\text { Consumidor - CDC }\end{array}$ & $48 \%$ & $15 \%(9)$ & $15 \%(9)$ & $10 \%(6)$ & $7 \%$ & $5 \%(3)$ & 2,3 & $(60)$ \\
\hline $\begin{array}{l}\text { Voluntariado empresarial e } \\
\text { apoio no enfrentamento de } \\
\text { calamidades }\end{array}$ & $3 \%(2)$ & $10 \%(6)$ & $5 \%(3)$ & $15 \%(9)$ & $27 \%$ & $40 \%$ & 4,7 & $(60)$ \\
\hline $\begin{array}{l}\text { Estimular, no ambiente de } \\
\text { trabalho, a comunicação } \\
\text { (diálogo), a cooperação e o } \\
\text { respeito mútuo }\end{array}$ & $5 \%(3)$ & $8 \%(5)$ & $3 \%$ & $23 \%(14)$ & $20 \%$ & $40 \%$ & 4,7 & $(60)$ \\
\hline
\end{tabular}

Respostas recebidas: 60 / Perguntas sem respostas: 00

Análise técnica - População:

60

\begin{tabular}{|c|c|}
\hline Programa de Qualidade de Vida no Trabalho - QVT & Conclusões destacadas \\
\hline Média & "75,00\%" escolheram: \\
\hline Intervalo de confiança $(95 \%)$ & Concordo Plenamente. \\
\hline Tamanho da amostra & Concordo Muito. \\
\hline Desvio padrão & $\begin{array}{l}\text { A opção menos escolhida } \\
\text { representa "1,67\%": }\end{array}$ \\
\hline Erro amostral & Discordo plenamente. \\
\hline Venda de seguro de vida e Crédito Direto ao Consumidor - CDC & Conclusões destacadas \\
\hline Média & "63,33\%" escolheram: \\
\hline Intervalo de confiança $(95 \%)$ & Discordo plenamente. \\
\hline Tamanho da amostra & Discordo Muito. \\
\hline Desvio padrão & $\begin{array}{l}\text { A opção menos escolhida } \\
\text { representa "5,00\%": }\end{array}$ \\
\hline Erro amostral & Concordo Plenamente. \\
\hline Voluntariado empresarial e apoio no enfrentamento de & Conclusões destacadas \\
\hline
\end{tabular}




\begin{tabular}{|c|c|c|}
\hline calamidades & & \\
\hline Média & 4,717 & \multirow{5}{*}{$\begin{array}{l}\text { "66,67\%" escolheram: } \\
\text { Concordo Plenamente. } \\
\text { Concordo Muito. } \\
\text { A opção menos escolhida } \\
\text { representa "3,33\%": } \\
\text { Discordo plenamente. }\end{array}$} \\
\hline Intervalo de confiança $(95 \%)$ & {$[4,347-5,087]$} & \\
\hline Tamanho da amostra & 60 & \\
\hline Desvio padrão & 1,462 & \\
\hline Erro amostral & 0,189 & \\
\hline $\begin{array}{l}\text { Estimular, no ambiente de tral } \\
\text { cooperação e o respeito mútuo }\end{array}$ & & \\
\hline Média & 4,650 & \multirow{5}{*}{$\begin{array}{l}\text { "63,33\%" escolheram: } \\
\text { Concordo Plenamente. } \\
\text { Concordo pouco. } \\
\text { A opção menos escolhida } \\
\text { representa "3,33\%": } \\
\text { Discordo pouco. }\end{array}$} \\
\hline Intervalo de confiança $(95 \%)$ & {$[4,272-5,028]$} & \\
\hline Tamanho da amostra & 60 & \\
\hline Desvio padrão & 1,494 & \\
\hline Erro amostral & 0,193 & \\
\hline
\end{tabular}

Tabela 07 - conhecimento dos funcionários sobre as ações sociais da empresa Fonte: Elaborado pelo formando

Como resultado, percebe-se na tabela 07 que existe bom discernimento, entre os questionados, quanto às práticas de caráter sócio responsável, implementadas pela empresa e somente 01 funcionário não reconheceu o programa de qualidade de vida no trabalho como sendo uma prática de responsabilidades social.

Na questão de $n^{\circ} 03$ buscamos verificar quanto a uma possível variação do grau de interesse do funcionário sobre as questões de responsabilidade social, durante os últimos cinco anos funcionário. Temos então no gráfico 03 a distribuição deste item do questionário.

Considero que as ações de caráter sócio responsável da empresa onde trabalho:

\begin{tabular}{|c|c|c|c|c|c|c|c|}
\hline & $\begin{array}{l}\text { Discordo } \\
\text { plenamente. }\end{array}$ & $\begin{array}{l}\text { Discordo } \\
\text { Muito. }\end{array}$ & $\begin{array}{l}\text { Discordo } \\
\text { pouco. }\end{array}$ & $\begin{array}{l}\text { Concordo } \\
\text { pouco. }\end{array}$ & $\begin{array}{l}\text { Concordo } \\
\text { Muito. }\end{array}$ & $\begin{array}{l}\text { Concordo } \\
\text { Plenamente. }\end{array}$ & MédiaTotal \\
\hline $\begin{array}{l}\text { a) contribuem para o aumento } \\
\text { do meu interesse por questões } \\
\text { de responsabilidade social }\end{array}$ & $3 \%(2)$ & $12 \%(7)$ & $13 \%(8)$ & $35 \%(21)$ & $28 \%(17)$ & $8 \%(5)$ & $4,0 \quad(60)$ \\
\hline
\end{tabular}

Tabela 08 - questão 04 - Aumento do interesse dos funcionários sobre responsabilidade social.

Com base na tabela de $n^{\circ} 08$ constatamos que dos 60 respondentes do questionário, 08 colaboradores concordam pouco com que seu interesse sobre 0 assunto aumentou. 17 concordam muito com a afirmativa 05 concordam plenamente, sendo $71 \%$ da população questionada teve seu interesse aumentado. Mas o que mais se destaca é o fato de que apenas 02 dos funcionários discordam totalmente da 
afirmativa de que seu interesse aumentou, enquanto $25 \%$ discordam pouco ou muito. O que mostra de certa forma que este tema obteve relativo ganho de espaço nos últimos anos na vida dos colaboradores neste setor do Banco do banco.

$\mathrm{Na}$ quinta questão buscamos verificar os meios pelos quais, e se, os funcionários buscam informações sobre as práticas, sócio responsáveis da empresa. Foram 05 opções seguintes a uma afirmativa, para as quais os questionados assinalaram o seu grau de concordância. A tabela 09 demonstra a reação do grupo:

5. Mantenho-me atualizado sobre as práticas sócio-responsáveis da empresa onde trabalho por meio de:

\begin{tabular}{|c|c|c|c|c|c|c|c|}
\hline & $\begin{array}{l}\text { Discordo } \\
\text { Totalmente }\end{array}$ & $\begin{array}{l}\text { Discordo } \\
\text { Muito }\end{array}$ & $\begin{array}{l}\text { Discordo } \\
\text { Pouco }\end{array}$ & $\begin{array}{l}\text { Concordo } \\
\text { Pouco }\end{array}$ & $\begin{array}{l}\text { Concordo } \\
\text { Muito }\end{array}$ & $\begin{array}{l}\text { Concordo } \\
\text { Totalmente. }\end{array}$ & Total \\
\hline $\begin{array}{l}\text { Jornais e periódicos } \\
\text { em geral; }\end{array}$ & $22 \%$ & $10 \%(6)$ & $20 \%(12)$ & $25 \%(15)$ & $10 \%(6)$ & $13 \%(8)$ & (60) \\
\hline $\begin{array}{l}\text { Informativos internos } \\
\text { da empresa onde } \\
\text { trabalho }\end{array}$ & $7 \%$ & $7 \%(4)$ & $13 \%(8)$ & $30 \%(18)$ & $28 \%(17)$ & $15 \%(9)$ & (60) \\
\hline $\begin{array}{l}\text { Conversas informais } \\
\text { no ambiente de } \\
\text { trabalho }\end{array}$ & $8 \%$ & $15 \%(9)$ & $12 \%(7)$ & $42 \%(25)$ & $13 \%(8)$ & $10 \%(6)$ & (60) \\
\hline $\begin{array}{l}\text { Conversas fora do } \\
\text { ambiente de trabalho }\end{array}$ & $30 \%(18)$ & $13 \%(8)$ & $13 \%(8)$ & $33 \%(20)$ & $8 \%(5)$ & $2 \%$ & (60) \\
\hline $\begin{array}{l}\text { Consultas ao site da } \\
\text { empresa onde trabalho }\end{array}$ & $20 \%(12)$ & $8 \%(5)$ & $20 \%(12)$ & $18 \%(11)$ & $27 \%(16)$ & $7 \%$ & (60) \\
\hline $\begin{array}{l}\text { Comerciais ou notícias } \\
\text { veiculadas pelo radio } \\
\text { ou televisão }\end{array}$ & $13 \%(8)$ & $13 \%(8)$ & $23 \%(14)$ & $22 \%(13)$ & $18 \%(11)$ & $8 \%$ & (59) \\
\hline $\begin{array}{l}\text { Não me interesso pelo } \\
\text { assunto. }\end{array}$ & $62 \%(37)$ & $10 \%(6)$ & $13 \%(8)$ & $7 \%$ & $7 \%(4)$ & $2 \%$ & (60) \\
\hline
\end{tabular}

Tabela 09 - questão 05 - Busca pela informação.

\begin{tabular}{|c|c|c|}
\hline Análise técnica - População: & 60 & \\
\hline Jornais e periódicos em geral; & & Conclusões destacadas \\
\hline Média & 3,317 & \multirow{5}{*}{$\begin{array}{l}\text { "46,67\%" escolheram: } \\
\text { Concordo Pouco } \\
\text { Discordo Totalmente } \\
\text { A opção menos escolhida representa } \\
\text { "10,00\%": } \\
\text { Discordo Muito }\end{array}$} \\
\hline Intervalo de confiança (95\%) & $\begin{array}{l}{[2,896-3,} \\
737]\end{array}$ & \\
\hline Tamanho da amostra & 60 & \\
\hline Desvio padrão & 1,662 & \\
\hline Erro amostral & $\mathbf{0 , 2 1 5}$ & \\
\hline Informativos internos da empresa onde trabalho & & Conclusões destacadas \\
\hline Média & 4,117 & "58,33\%" escolheram: \\
\hline Intervalo de confiança $(95 \%)$ & $\begin{array}{l}{[3,768-4,} \\
466]\end{array}$ & Concordo Pouco \\
\hline Tamanho da amostra & 60 & Concordo Muito \\
\hline
\end{tabular}




\begin{tabular}{|c|c|c|}
\hline Desvio padrão & 1,379 & $\begin{array}{l}\text { A opção menos escolhida representa } \\
\text { "6,67\%": }\end{array}$ \\
\hline Erro amostral & $\mathbf{0 , 1 7 8}$ & Discordo Totalmente \\
\hline Conversas informais no ambiente de trabalho & & \multirow{6}{*}{$\begin{array}{l}\text { Conclusões destacadas } \\
\text { "56,67\%" escolheram: } \\
\text { Concordo Pouco } \\
\text { Discordo Muito } \\
\text { A opção menos escolhida representa } \\
\text { "8,33\%": } \\
\text { Discordo Totalmente } \\
\end{array}$} \\
\hline Média & 3,667 & \\
\hline Intervalo de confiança $(95 \%)$ & $\begin{array}{l}{[3,316 \text { - 4, }} \\
017]\end{array}$ & \\
\hline Tamanho da amostra & 60 & \\
\hline Desvio padrão & 1,386 & \\
\hline Erro amostral & $\mathbf{0 , 1 7 9}$ & \\
\hline Conversas fora do ambiente de trabalho & & \multirow{6}{*}{\begin{tabular}{|l|} 
Conclusões destacadas \\
$63,33 \% "$ escolheram: \\
Concordo Pouco \\
Discordo Totalmente \\
A opção menos escolhida representa \\
"1,67\%": \\
Concordo Totalmente.
\end{tabular}} \\
\hline Média & 2,817 & \\
\hline Intervalo de confiança $(95 \%)$ & $\begin{array}{l}{[2,445 \text { - 3, }} \\
188]\end{array}$ & \\
\hline Tamanho da amostra & 60 & \\
\hline Desvio padrão & 1,467 & \\
\hline Erro amostral & $\mathbf{0 , 1 8 9}$ & \\
\hline Consultas ao site da empresa onde trabalho & & \multirow{6}{*}{$\begin{array}{l}\text { Conclusões destacadas } \\
46,67 \% " \text { escolheram: } \\
\text { Concordo Muito } \\
\text { Discordo Totalmente } \\
\text { A opção menos escolhida representa } \\
\text { "6,67\%": } \\
\text { Concordo Totalmente. }\end{array}$} \\
\hline Média & 3,433 & \\
\hline Intervalo de confiança (95\%) & $\begin{array}{l}{[3,026 \text { - 3, }} \\
840]\end{array}$ & \\
\hline Tamanho da amostra & 60 & \\
\hline Desvio padrão & 1,609 & \\
\hline Erro amostral & $\mathbf{0 , 2 0 8}$ & \\
\hline Comerciais ou notícias veiculadas pelo radio ou televisão & & \multirow{6}{*}{$\begin{array}{l}\text { Conclusões destacadas } \\
\text { "45,00\%" escolheram: } \\
\text { Discordo Pouco } \\
\text { Concordo Pouco } \\
\text { A opção menos escolhida representa } \\
\text { "8,33\%": } \\
\text { Concordo Totalmente. }\end{array}$} \\
\hline Média & 3,441 & \\
\hline Intervalo de confiança $(95 \%)$ & $\begin{array}{l}{[3,058 \text { - 3, }} \\
823]\end{array}$ & \\
\hline Tamanho da amostra & 59 & \\
\hline Desvio padrão & 1,500 & \\
\hline Erro amostral & 0,195 & \\
\hline Não me interesso pelo assunto. & & \multirow{6}{*}{$\begin{array}{l}\text { Conclusões destacadas } \\
75,00 \% " \text { escolheram: } \\
\\
\text { Discordo Totalmente } \\
\text { Discordo Pouco } \\
\text { A opção menos escolhida representa } \\
\text { "1,67\%": } \\
\text { Concordo Totalmente. }\end{array}$} \\
\hline Média & 1,917 & \\
\hline Intervalo de confiança (95\%) & $\begin{array}{l}{[1,567-2,} \\
266]\end{array}$ & \\
\hline Tamanho da amostra & 60 & \\
\hline Desvio padrão & 1,381 & \\
\hline Erro amostral & $\mathbf{0 , 1 7 8}$ & \\
\hline
\end{tabular}

Observamos por meio da tabela 09 e da análise técnica referente a cada opção, que os meios externos são pouco usados sendo que $77 \%$ dos funcionários concordaram pouco ou discordaram plenamente quanto ao uso de Jornais e periódicos em geral como fonte de informação. Mais de $58 \%$ dos respondentes concorda que busca informações nos informativos internos e $65 \%$ concorda que conversas informais são importantes e ajudam na atualização, enquanto que $52 \%$ concordam que buscam informações no site interno da empresa. A questão 05 conclui que os meios internos 
de informação são bem procurados pelos colaboradores questionados, o que pode ser confirmado pelo item "a" da tabela 10 referente à questão de $n^{\circ} 06$.

A pergunta feita na questão de $n^{\circ} 06$ verificou junto aos assistentes como eles avaliam as informações e o treinamento, oferecidos pela empresa aos seus colaboradores internos, a cerca do tema responsabilidade social. A tabela 10 apresenta a distribuição dessa questão.

6. A empresa onde trabalho disponibiliza:

a) informações sobre as suas ações de responsabilidade social, aos seus

Discordo Discordo Discordo Concordo Concordo Concordo
Totalmente
Pouco Pouco Muito Totalmente. $3 \%(2)$ $10 \%$ (6) $17 \%$ (10) $35 \%$ (21) $22 \%$ (13) $12 \%(7)$ 4,0

b) treinamento voltado ao tema responsabilidade social, acessível e de qualidade.

Respostas recebidas: 60 / Perguntas sem respostas: 00

\begin{tabular}{|l|r|r|}
\hline Análise técnica - População: & 60 \\
\hline a) informações sobre as suas ações de responsabilidade social, aos seus funcionários. & Conclusões destacadas \\
\hline Média & 3,983 & "56,67\%" escolheram: \\
\hline Intervalo de confiança (95\%) & {$[3,660-4,306]$} & Concordo Pouco \\
\hline Tamanho da amostra & 59 & Concordo Muito \\
\hline Desvio padrão & 1,266 & A opção menos escolhida representa "3,33\%": \\
\hline Erro amostral & 0,165 & Discordo Totalmente \\
\hline
\end{tabular}

\begin{tabular}{|l|r|r|}
\hline b) treinamento voltado ao tema responsabilidade social, acessível e de qualidade. & Conclusões destacadas \\
\hline Média & 3,350 & "46,67\%" escolheram: \\
\hline Intervalo de confiança (95\%) & {$[2,999-3,701]$} & Discordo Pouco \\
\hline Tamanho da amostra & 60 & Concordo Pouco \\
\hline Desvio padrão & 1,388 & A opção menos escolhida representa "3,33\%": \\
\hline Erro amostral & 0,179 & Concordo Totalmente. \\
\hline
\end{tabular}

Tabela 10 - Questão 06 - Informações e treinamento

Da questão de número 07 até a questão de número 10 buscamos avaliar a percepção dos colaboradores vinculados ao setor quanto ao Programa de Qualidade de Vida no Trabalho - QVT. O resultado esta ilustrado nas tabelas seguintes: 
7. Eu conheço e sei o que é: O Programa QVT implantado pela empresa onde trabalho.

$\begin{array}{llllllll}\begin{array}{l}\text { Discordo } \\ \text { Totalmente }\end{array} & \begin{array}{l}\text { Discordo } \\ \text { Muito }\end{array} & \text { Discordo Pouco } & \begin{array}{c}\text { Concordo } \\ \text { Pouco }\end{array} & \begin{array}{l}\text { Concordo } \\ \text { Muito }\end{array} & \begin{array}{c}\text { Concordo } \\ \text { Totalmente. }\end{array} & \text { Média Total } \\ \mathbf{5 \%}(\mathbf{3}) & \mathbf{7 \%}(\mathbf{4}) & \mathbf{1 8 \% ( 1 1 )} & \mathbf{1 7 \%}(\mathbf{1 0}) & \mathbf{4 0 \%}(\mathbf{2 4}) & \mathbf{1 3 \%}(\mathbf{8}) & 4,2 & (60)\end{array}$

Respostas recebidas: 60/ Perguntas sem respostas: 0

\begin{tabular}{|c|c|c|}
\hline Análise técnica - População: & 60 & \\
\hline O Programa QVT implantado pela empresa onde trabalho. & & Conclusões destacadas \\
\hline Média & 4,200 & "58,33\%" escolheram: \\
\hline Intervalo de confiança (95\%) & {$[3,858-4,542]$} & Concordo Muito \\
\hline Tamanho da amostra & 60 & Discordo Pouco \\
\hline Desvio padrão & 1,350 & A opção menos escolhida representa "5,00\%": \\
\hline Erro amostral & 0,174 & Discordo Totalmente \\
\hline
\end{tabular}

A tabela de número 11 demonstra que $70 \%$ dos questionados concorda com a afirmativa. 25\% manifestaram algum grau de discordância, enquanto que apenas 05\%, ou seja, apenas 03 em um total de 60 desconhecem completamente o referido programa. O resultado revela que a maioria dos funcionários do setor sabe do que se trata o programa QVT adotado pela empresa.

A questão 08 dividiu-se em dois (02) itens que buscam avaliar a percepção dos colaboradores quanto ao grau de motivação de seus pares e sobre alguma melhoria da qualidade de vida no trabalho a partir da promoção do estilo de vida saudável proporcionada pelo referido programa.

8. Na empresa, em que trabalho, percebe-se que:

a) Meus colegas de trabalho sentem-se motivados em conhecer e participar das atividades desenvolvidas pelo programa QVT

\begin{tabular}{|c|c|c|}
\hline & & Conclusões destacadas \\
\hline Média & 3,102 & "54,24\%" escolheram: \\
\hline Intervalo de confiança (95\%) & {$[2,748-3,455]$} & Discordo Pouco \\
\hline Tamanho da amostra & 59 & Concordo Pouco \\
\hline Desvio padrão & 1,386 & A opção menos escolhida representa "3,39\%": \\
\hline Erro amostral & 0,180 & Concordo Totalmente. \\
\hline \multicolumn{3}{|c|}{$\begin{array}{l}\text { b) O programa QVT implantado na empresa promove a melhoria da qualidade de vida no trabalho a partir da promoção do } \\
\text { estilo de vida saudável. }\end{array}$} \\
\hline Média & 3,441 & $\begin{array}{l}\text { Conclusões destacadas } \\
\text { "52,54\%" escolheram: }\end{array}$ \\
\hline Intervalo de confiança (95\%) & {$[3,088-3,793]$} & Concordo Pouco \\
\hline Tamanho da amostra & 59 & Discordo Pouco \\
\hline Desvio padrão & 1,381 & $\begin{array}{l}\text { A opção menos escolhida representa } \\
\text { "6,78\%": }\end{array}$ \\
\hline Erro amostral & 0,180 & Concordo Totalmente. \\
\hline 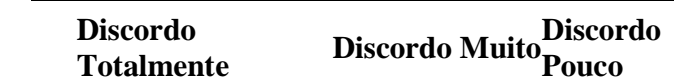 & $\begin{array}{l}\text { Concordo } \\
\text { Pouco }\end{array}$ & $\begin{array}{l}\text { Concordo } \\
\text { Totalmente. }\end{array}$ \\
\hline
\end{tabular}




\begin{tabular}{|c|c|c|c|c|c|c|c|c|}
\hline a) & $19 \%(11)$ & $10 \%(6)$ & $34 \%$ & $20 \%$ & $14 \%(8)$ & $3 \%(2)$ & 3,1 & (59) \\
\hline b) & $10 \%(6)$ & $15 \%(9)$ & $24 \%$ & $29 \%(17)$ & $15 \%(9)$ & $7 \%$ & 3,4 & (59) \\
\hline
\end{tabular}

Tabela 12 - Programa QVT

No item "a", que se refere à motivação verificamos um percentual elevado de discordância quanto à afirmativa, onde $63 \%$ de discordância contra $37 \%$ que revela na percepção da maioria dos colaboradores um baixo índice de motivação relacionado ao programa QVT, no setor.

Quanto à melhoria da qualidade de vida no trabalho a partir da promoção do estilo de vida saudável, em conseqüência do programa QVT, constatamos por meio do item "b" da questão 08 , que na percepção dos colaboradores o resultado ficou dividido, com $49 \%$ de discordância e 51\% concordância com a afirmativa, onde 10\% discordam plenamente e $07 \%$ concordam plenamente, sendo que apenas (01) uma pessoa não respondeu.

A questão de número 09 buscava averiguar a percepção dos colaboradores quanto aos fatores que porventura possam influenciar nos resultados visados pela empresa ao implantar o Programa de qualidade de vida no trabalho - QVT. Foram elencados aleatoriamente fatores internos e externos e a tabela $\mathrm{N}^{\circ} 13$ ilustra, a seguir, os resultados obtidos.

09. Percebo que as ações e resultados do Programa Qualidade de Vida no Trabalho, implementado pela empresa, são influenciados pelos fatores:

\begin{tabular}{|c|c|c|c|c|c|c|}
\hline & $\begin{array}{l}\text { Discordo } \\
\text { Totalmen Discordo Muito } \\
\text { te }\end{array}$ & $\begin{array}{cc}\text { Discordo } & \text { Concordo } \\
\text { Pouco } & \text { Pouco }\end{array}$ & $\begin{array}{l}\text { Concordo } \\
\text { Muito }\end{array}$ & $\begin{array}{c}\text { Concordo } \\
\text { Totalmente }\end{array}$ & $\begin{array}{l}\text { Méd } \\
\text { ia }\end{array}$ & Total \\
\hline a)Legislação, lei das licitações & $13 \%(8) 10 \%(6)$ & $20 \%(12) 23 \%$ & $20 \%(12)$ & $13 \%(8)$ & 3,7 & (60) \\
\hline $\begin{array}{l}\text { b)Interesse do Comitê de } \\
\text { Administração da dependência }\end{array}$ & $15 \%(9)$ & $20 \%(12) 37 \%$ & $13 \%(8)$ & $10 \%(6)$ & 3,6 & $(60)$ \\
\hline $\begin{array}{l}\text { c)Competência dos Agentes de } \\
\text { Comunicação Interna }\end{array}$ & $8 \%(5)$ & $27 \%(16) 35 \%$ & $12 \%(7)$ & $12 \%(7)$ & 3,7 & $(60)$ \\
\hline $\begin{array}{l}\text { d)Falta de interesse coletivo dos } \\
\text { funcionários }\end{array}$ & $7 \%(4)$ & $20 \%(12) 40 \%$ & $22 \%(13)$ & $10 \%(6)$ & 4,0 & $(60)$ \\
\hline $\begin{array}{l}\text { e)Sistemas de comunicação } \\
\text { formal e informal entre os } \\
\text { diversos níveis hierárquicos da } \\
\text { dependência }\end{array}$ & $10 \%(6)$ & $25 \%$ & $15 \%(9)$ & $7 \%(4)$ & 3,6 & $(60)$ \\
\hline
\end{tabular}


f)Promoção da interação intergrupal e o incentivo a prática da comunicação interpessoal nas equipes e na dependência

\begin{tabular}{|c|c|c|}
\hline Análise técnica - População: & \multicolumn{2}{|l|}{60} \\
\hline \multicolumn{2}{|l|}{ a) Legislação, lei das licitações } & Conclusões destacadas \\
\hline Média & 3,667 & "43,33\%" escolheram: \\
\hline Intervalo de confiança $(95 \%)$ & {$[3,270-4,064]$} & Concordo Pouco \\
\hline Tamanho da amostra & 60 & Discordo Pouco \\
\hline Desvio padrão & 1,569 & $\begin{array}{l}\text { A opção menos escolhida representa } \\
\text { "10,00\%": }\end{array}$ \\
\hline Erro amostral & 0,203 & Discordo Muito \\
\hline \multicolumn{2}{|c|}{ b) Interesse do Comitê de Administração da dependência } & Conclusões destacadas \\
\hline Média & 3,583 & "56,67\%" escolheram: \\
\hline Intervalo de confiança (95\%) & {$[3,213-3,954]$} & Concordo Pouco \\
\hline Tamanho da amostra & 60 & Discordo Pouco \\
\hline Desvio padrão & 1,465 & $\begin{array}{l}\text { A opção menos escolhida representa } \\
\text { "5,00\%": }\end{array}$ \\
\hline Erro amostral & $\mathbf{0 , 1 8 9}$ & Discordo Muito \\
\hline
\end{tabular}

\begin{tabular}{|c|c|c|}
\hline \multicolumn{2}{|c|}{ c) Competência dos Agentes de Comunicação Interna } & \multirow{6}{*}{\begin{tabular}{|l} 
Conclusões destacadas \\
"61,67\%" escolheram: \\
Concordo Pouco \\
Discordo Pouco \\
A opção menos escolhida representa \\
"6,67\%": \\
Discordo Totalmente \\
\end{tabular}} \\
\hline Média & 3,717 & \\
\hline Intervalo de confiança $(95 \%)$ & {$[3,384-4,050]$} & \\
\hline Tamanho da amostra & 60 & \\
\hline Desvio padrão & 1,316 & \\
\hline Erro amostral & $\mathbf{0 , 1 7 0}$ & \\
\hline \multicolumn{2}{|c|}{ d) Falta de interesse coletivo dos funcionários } & Conclusões destacadas \\
\hline Média & 3,983 & "61,67\%" escolheram: \\
\hline Intervalo de confiança $(95 \%)$ & {$[3,673-4,294]$} & Concordo Pouco \\
\hline Tamanho da amostra & 60 & Concordo Muito \\
\hline Desvio padrão & 1,228 & $\begin{array}{l}\text { A opção menos escolhida representa } \\
\text { "1,67\%": }\end{array}$ \\
\hline Erro amostral & 0,159 & Discordo Muito \\
\hline \multicolumn{2}{|c|}{$\begin{array}{l}\text { e) Sistemas de comunicação formal e informal entre os diversos níveis } \\
\text { hierárquicos da dependêcia }\end{array}$} & Conclusões destacadas \\
\hline Média & 3,633 & "63,33\%" escolheram: \\
\hline Intervalo de confiança $(95 \%)$ & {$[3,307-3,959]$} & Concordo Pouco \\
\hline Tamanho da amostra & 60 & Discordo Pouco \\
\hline Desvio padrão & 1,288 & $\begin{array}{l}\text { A opção menos escolhida representa } \\
\text { "5,00\%": }\end{array}$ \\
\hline Erro amostral & 0,166 & Discordo Muito \\
\hline
\end{tabular}

f) Promoção da interação inter-grupal e o incentivo a prática da comunicação interpessoal nas equipes e na dependência

\begin{tabular}{ll|l} 
Média & $\mathbf{3 , 7 0 0}$ & Conclusões destacadas \\
Intervalo de confiança $(\mathbf{9 5 \%})$ & {$[3, \mathbf{3 6 6}-\mathbf{4 , 0 3 4 ]}$} & $\begin{array}{c}55,00 \% " \\
\text { Concordo Pouco }\end{array}$
\end{tabular}


Tamanho da amostra

Desvio padrão

Erro amostral
60

1,319

$\mathbf{0 , 1 7 0}$
Concordo Muito

A opção menos escolhida representa "5,00\%":

Concordo Totalmente.

Tabela 13 - Programa QVT

A questão de número (10) dez, última do questionário buscou responder ao objetivo principal deste trabalho. O resultado está descrito, na tabela seguinte:

\begin{tabular}{|c|c|c|c|c|c|c|c|c|}
\hline & $\begin{array}{l}\text { Discordo } \\
\text { Totalmente }\end{array}$ & $\begin{array}{l}\text { Discordo } \\
\text { Muito }\end{array}$ & $\begin{array}{l}\text { Discordo } \\
\text { Pouco }\end{array}$ & $\begin{array}{l}\text { Concordo } \\
\text { Pouco }\end{array}$ & $\begin{array}{l}\text { Concordo } \\
\text { Muito }\end{array}$ & $\begin{array}{l}\text { Concordo } \\
\text { Totalmente. }\end{array}$ & Média & Total \\
\hline $\begin{array}{l}\text { Uma prática sócio } \\
\text { responsável, de caráter } \\
\text { interno, efetiva. }\end{array}$ & $2 \%(1)$ & $19 \%(11)$ & $26 \%$ & $42 \%(24)$ & $9 \%(5)$ & $2 \%(1)$ & 3,4 & (57) \\
\hline
\end{tabular}

Análise técnica - População:

\begin{tabular}{|c|c|c|}
\hline Média & 3,421 & $\begin{array}{l}\text { Conclusões destacadas } \\
\text { "68,42\%" escolheram: }\end{array}$ \\
\hline Intervalo de confiança (95\%) & {$[3,157-3,685]$} & Concordo Pouco \\
\hline Tamanho da amostra & 57 & Discordo Pouco \\
\hline Desvio padrão & 1,017 & $\begin{array}{l}\text { A opção menos escolhida representa } \\
\text { "1,75\%": }\end{array}$ \\
\hline Erro amostral & 0,135 & Discordo Totalmente \\
\hline
\end{tabular}

\section{Tabela 14}

Fonte - elaborada pelo formando

No total de 60 questionários 57 foram respondidos e apenas três ficaram sem resposta nesta questão, onde $53 \%$, ou seja, pouco mais da metade dos Assistentes lotados no setor concordam com a afirmativa. 


\section{CONSIDERAÇÕES FINAIS}

Este trabalho, desde a escolha do tema e a formulação da questão de pesquisa, assim como a elaboração do referencial teórico, passando pela busca por informações relevantes e a análise dos dados até chegarmos a esta etapa, demandou considerado esforço do formando. Alguns fatores, como disponibilidade de tempo para realização das pesquisas e a colaboração dos colegas de banco durante da aplicação dos questionários, exigiram elevado grau de persistência.

Consideramos ter realizado com sucesso o alcance dos objetivos propostos no trabalho. O vínculo do autor com a instituição bancária, cenário desta pesquisa permitiu o acesso as informações desejadas de forma direta. Também a empresa possui diversas fontes de divulgação em seus sites na internet, cujos relatórios possibilitaram a caracterização do programa QVT adotado pelo banco.

Passamos, então, para o segundo objetivo, por meio da elaboração de um questionário como instrumento de coleta de dados. O questionário foi composto por itens que exigiram dos participantes relativa atenção, sendo que as questões relacionavam a análise de sua percepção, podendo expor respostas contraditórias. Foi testado o grau de conhecimento dos respondentes em relação ao conceito de responsabilidade social e as ações que caracterizam o programa QVT do banco. Os dados foram tratados e apresentados por meio de tabelas mensurando as respostas dos colaboradores e assim se pôde analisar a percepção dos funcionários em relação ao tema da pesquisa.

A questão principal referente ao problema de pesquisa foi: Os colaboradores internos vinculados a unidade Risco União - DF do Banco Nacional S/A reconhecem o Programa Qualidade de Vida no Trabalho - QVT, adotado pela empresa como uma prática, sócio responsável de caráter interno, efetiva?

Concluímos que os colaboradores internos têm um grau satisfatório de conhecimento a cerca do conceito responsabilidade social e existe forte grau de 
incerteza quanto à percepção do programa QVT adotado pela empresa como efetivo, sendo que $53 \%$, ou seja, pouco mais da metade dos Assistentes lotados no setor concordam com a afirmativa.

Consideramos que a escolha do método de pesquisa utilizado foi adequada, uma vez que se enquadrou em um conjunto de atividades ordenadas e coerentes que nos permitiu o alcance dos objetivos e a apresentação de como a pesquisa foi caracterizada, como foi feita a coleta de dados e, como se deu o tratamento e análise dos dados.

O Banco Nacional S. A é responsável pela condução e administração de um grupo de operações cujo risco de crédito é da União, porém nada obstante a União assumir o risco de crédito dessas operações, o Banco assume o risco operacional decorrente de falhas/irregularidades verificadas nas operações que impeçam o recebimento dos valores devidos pelos mutuários, quer administrativamente quer pela via judicial por meio da Dívida Ativa.

setor RISCO UNIÃO recentemente criado, ainda passa por uma série de adaptações tanto no aspecto operacional, como treinamento de pessoal e adequação de rotinas quanto no aspecto de ambiente de trabalho, tendo sido instalado em um prédio provisório e com uma série de carências estruturais e que, muitas vezes não é atendido pelo programa QVT, por motivos circunstanciais.

Neste contexto os funcionários participantes da pesquisa e que compõe o primeiro escalão de comissionados do Setor Risco União responderam aos questionários durante horário de trabalho em meio ao afazeres complexos que exigem muita atenção, muitas vezes com interferências de chamadas telefônicas e questionamentos de diferentes assuntos por parte de clientes e outros funcionários.

Esta é uma limitação que julgamos ter encontrado na pesquisa, pois, pode ter alguma influência nas respostas em se tratando do fato de que a atenção nas respostas era de total relevância, possibilitando a interferência em alguma resposta que poderia ser diferente se o funcionário estivesse em um local sob condições controladas e adequado para focar-se na pesquisa. 
Apesar deste fator que pode, ou não, ter influenciado no resultado do trabalho, para o formando fica a satisfação em relação à experiência do exercício da pesquisa acadêmica e do conhecimento adquirido sobre este tema fascinante que é o da responsabilidade social além da contribuição deste trabalho para conscientização da administração daquela unidade do banco quanto à necessidade de melhoria das condições de trabalho naquele ambiente e do acesso aos benefícios do programa QVT. 


\section{REFERÊNCIAS}

AKER, David A. KUMAR, V. DAY, George S. Pesquisa de Marketing. São Paulo. Editora Atlas, 2001

ACEVEDO, Claudia Rosa; NOHARA, Jouliana Jordan. Monografia no Curso de Administração. Atlas - SP, 2009.

ASHLEY, Patrícia Almeida (coord.). Ética e responsabilidade social nos negócios. São Paulo: Saraiva 2002.

CHIAVENATO, Idalberto. Recursos Humanos: Ed. Compacta. 6. Ed. São Paulo: Atlas, 2000 p. 631

DIAS, Reinaldo. Gestão Ambiental: Responsabilidade social e sustentabilidade. São Paulo: Editora Atlas S.A., 2008. FAPSE - Universidade de Genebra.

FLEURY, Maria Tereza Leme. As Pessoas na Organização. São Paulo: Gente, 2002.

HAIR Jr., Joseph F.; BABIN, Barry; MONEY, Arthur H.; SAMOUEL, Phillip. Fundamentos de métodos de pesquisa em administração. Tradução: RIBEIRO, Lene Belon. Porto Alegre: Bookman, 2005.

INSTITUTO ETHOS DE EMPRESAS E RESPONSABILIDADE SOCIAL ETHOS. Institucional. http://www.ethos.org.br/docs/institucional/perguntas.shtml Acesso em: agosto de 2010.

JONAS, Fábio M. UMA INVESTIGAÇÃO EMPÍRICA SOBRE A RELAÇÃO ENTRE JUSTIÇA, COMPROMETIMENTO E CIDADANIA ORGANIZACIONAL. Dissertação de Mestrado Profissionalizante apresentada ao Programa de Pós-Graduação em Administração e Economia das Faculdades IBMEC. Rio de Janeiro: 2009. Disponível em: http://www.ibmecrj.br/sub/RJ/files/dissert_mestrado/ADM_fabiojonas_dez.pdf. Acesso em 10 out. 2010.

LIPP, M. Pesquisa sobre stress no Brasil: saúde, ocupações e grupos de risco. Campinas: Papirus, 1996.

MALHOTRA, Naresh K. Pesquisa de marketing: uma orientação aplicada. $3^{\circ}$ ed. Porto alegre: Bookman, 2001.

MELO NETO, Francisco Paulo de; FROES, Cesar. Responsabilidade Social e Cidadania Empresarial: A administração do Terceiro Setor. Rio de Janeiro: Qualitymark, 1999.

ROESCH, Sylvia Maria Azevedo. Projetos de Estágio e de Pesquisa em Administração. Atlas, SP 3르. 2009.

YIN, Robert K. Estudo de caso. Planejamento e métodos. Tradução Daniel Grassi. (3ª edição). Porto Alegre: Bookman, 2005.

SILVEIRA, Alexandre Di Miceli da; YOSHINAGA, Claudia Emiko;

BORBA, Paulo da Rocha Ferreira. Crítica à teoria dos stakeholders como funçãoobjetivo corporativa. REGE-USP, São Paulo, v. 12, n. 1, mar. 2005 . Disponível 
em <http://www.revistasusp.sibi.usp.br/scielo.php?script=sci_arttext\&pid=S1809$22762005000100004 \&$ Ing=pt\&nrm=iso>. acessos em 15 out. 2010 http://www.bb.com.br/portalbb/page3,102,2685,0,0,1,6.bb?codigoNoticia=1546\&codi goRet $=1312 \&$ bread $=1 \&$ codigoMenu=643 acessos em 14.out. 2010 


\section{Apêndice A}

\section{Responsabilidade Social - 1058533/EAD - UNB Questionário aplicado pessoalmente em 24/09/2010}

\section{Dados Pessoais}

Gênero: $\square$ Masculino $\square$ Feminino

Idade:__anos

Escolaridade: $\square 2^{\circ}$ grau $\square$ Superior $\square$ Pós graduação

Tempo de Empresa: anos.

Foi seu primeiro emprego? $\square \operatorname{Sim} \square$ Não

Onde você trabalhava antes de vir para este setor:

Cidade: Estado:

Assinale seu grau de concordância ou discordância em relação ao enunciado, de acordo com a seguinte escala:

1-Discordo Totalmente; 2- Discordo Muito; 3-Discordo Pouco; 4-Concordo Pouco; 5-Concordo Muito; e 6- Concordo Totalmente.

1. I_ Eu sei o que é responsabilidade Social.

2. As práticas listadas abaixo, implantadas pela instituição onde você trabalha, podem ser consideradas ações de responsabilidade social:

L__ Programa de Qualidade de Vida no Trabalho - QVT

L__ Venda de seguro de vida e Crédito Direto ao Consumidor - CDC

____ Voluntariado empresarial e apoio no enfrentamento de calamidades;

L__ Estimular, no ambiente de trabalho, a comunicação, a cooperação e o respeito mútuo.

3. ـ__ Nos últimos 05 (cinco) anos sinto que meu interesse por questões de responsabilidade social aumentou.

4. ـ__ Considero que as ações de caráter sócio responsável da empresa, onde trabalho contribuem para o aumento do meu interesse por questões de responsabilidade social

5. Mantenho-me atualizado sobre as possíveis novas práticas sócio-responsáveis da empresa onde trabalho através de: 
L__ Jornais e periódicos em geral;

L__ Informativos internos da empresa onde trabalho;

____ Não me interesso pelo assunto;

L__ Conversas fora do ambiente de trabalho;

L__ Consultas ao site da empresa onde trabalho;

___ Comerciais ou notícias veiculadas pelo radio ou televisão;

L__ Conversas informais no ambiente de trabalho;

6. A empresa onde trabalho disponibiliza:

a) \__ informações sobre as suas ações de responsabilidade social, aos seus funcionários.

b) $\_$__ t treinamento voltado ao tema responsabilidade social, acessível e de qualidade.

7. |_ Eu conheço e sei o que é o Programa QVT implantado pela empresa onde trabalho.

6. A empresa onde trabalho disponibiliza:

7. ـ__ Eu conheço e sei o que é o Programa QVT implantado pela empresa onde trabalho

a) \__ informações sobre as suas ações de responsabilidade social, aos seus funcionários.

b) I__ t treinamento voltado ao tema responsabilidade social, acessível e de qualidade.

8. Na empresa, em que trabalho, percebo que:

_ Meus colegas de trabalho sentem-se motivados em conhecer e participar das atividades desenvolvidas pelo programa QVT;

L__ O programa QVT implementado pela empresa promove a melhoria da qualidade de vida no trabalho a partir da promoção do estilo de vida saudável.

9. Percebo que as ações e resultados do Programa Qualidade de Vida no Trabalho, implementado pela empresa, são influenciados pelos fatores:

a) |__ Legislação, lei das licitações.

b) |__ Interesse do Comitê de Administração da dependência.

c) |__ Competência dos Agentes de Comunicação Interna.

d) $\mid$ _ _ Falta de interesse coletivo dos funcionários.

e) L_ _ Sistemas de comunicação formal e informal entre os diversos níveis hierárquicos da dependência

f) $\perp_{\text {__ _ }}$ Promoção da interação intergrupal e o incentivo a prática da comunicação interpessoal nas equipes e na dependência

10. ـ__ O Programa Qualidade de vida no Trabalho - QVT, implementado pela empresa é uma prática sócio responsável de caráter interno, efetiva. 